\title{
Kalirin/Trio Rho GDP/GTP exchange factors regulate proinsulin and insulin secretion
}

\author{
Quinn Dufurrena1, Nils Bäck², Richard Mains³, Louis Hodgson4, Herbert Tanowitz5, Prashant Mandela6, \\ Betty Eipper7 and Regina Kuliawat ${ }^{8}$ \\ 1Department of Medicine, Stony Brook University School of Medicine, Stony Brook, New York, USA \\ 2Department of Anatomy, Faculty of Medicine, University of Helsinki, Helsinki, Finland \\ ${ }^{3}$ Department of Neuroscience, University of Connecticut Health Center, Farmington, Connecticut, USA \\ ${ }^{4}$ Department of Anatomy and Structural Biology, Albert Einstein College of Medicine, Bronx, New York, USA \\ 5Departments of Pathology, Medicine, Albert Einstein College of Medicine, Bronx, New York, USA \\ ${ }^{6}$ School of Pharmacy, University of Saint Joseph, Hartford, Connecticut, USA \\ ${ }^{7}$ Department of Molecular Biology and Biophysics, University of Connecticut Health Center, Farmington, Connecticut, USA \\ ${ }^{8}$ Developmental and Molecular Biology, Albert Einstein College of Medicine, Bronx, New York, USA
}

Correspondence should be addressed to R Kuliawat: regina.kuliawat@einstein.yu.edu

\begin{abstract}
Key features for progression to pancreatic $\beta$-cell failure and disease are loss of glucose responsiveness and an increased ratio of secreted proinsulin to insulin. Proinsulin and insulin are stored in secretory granules (SGs) and the fine-tuning of hormone output requires signal-mediated recruitment of select SG populations according to intracellular location and age. The GTPase Rac1 coordinates multiple signaling pathways that specify SG release, and Rac1 activity is controlled in part by GDP/GTP exchange factors (GEFs). To explore the function of two large multidomain GEFs, Kalirin and Trio in $\beta$-cells, we manipulated their Rac1-specific GEF1 domain activity by using small-molecule inhibitors and by genetically ablating Kalirin. We examined age-related SG behavior employing radiolabeling protocols. Loss of Kalirin/Trio function attenuated radioactive proinsulin release by reducing constitutive-like secretion and exocytosis of 2-h-old granules. At later chase times or at steady state, Kalirin/Trio manipulations decreased glucosestimulated insulin output. Finally, use of a Rac1 FRET biosensor with cultured $\beta$-cell lines demonstrated that Kalirin/Trio GEF1 activity was required for normal rearrangement of Rac1 to the plasma membrane in response to glucose. Rac1 activation can be evoked by both glucose metabolism and signaling through the incretin glucagon-like peptide 1 (GLP-1) receptor. GLP-1 addition restored Rac1 localization/activity and insulin secretion in the absence of Kalirin, thereby assigning Kalirin's participation to stimulatory glucose signaling.
\end{abstract}

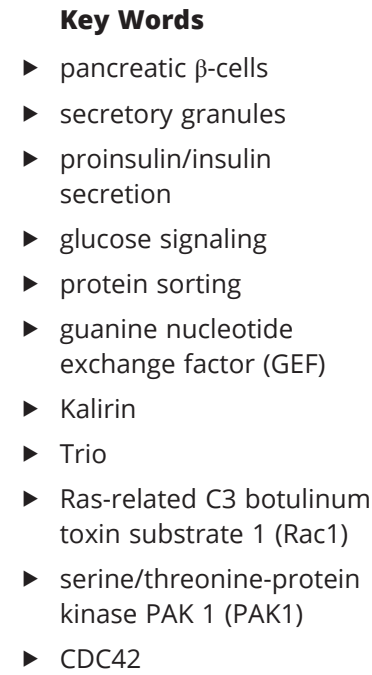

Journal of Molecular Endocrinology (2019) 62, 47-65

\section{Introduction}

The pancreatic $\beta$-cell, the cell type that coordinates the complex molecular repertoire of nutrient signaling and hormone output, accurately estimates the insulin need a particular meal creates (Low et al. 2013, Wilson et al. 2017).
Thus, in healthy individuals, cellular mechanisms match insulin release to demand, restricting circulating amounts of glucose to a very narrow range. Research over the last decade has identified lists of candidate genes that 
correlate with diabetes susceptibility and one key feature for progression to $\beta$-cell failure is loss of glucose sensitivity and an increased ratio of secreted proinsulin to insulin. The model we have tested in this report is that select guanine nucleotide exchange factors (GEFs) regulate glucose responsiveness and proinsulin secretion.

Formation of new SGs starts with granule cargo protein aggregation in the trans-Golgi Network (TGN) (Arvan \& Castle 1998, Tooze et al. 2001, Loh et al. 2004). After budding from the TGN, both the composition of immature secretory granule (ISG) membranes and their soluble content change (Arvan \& Castle 1998, Borgonovo et al. 2006). Proinsulin, the major soluble secretory cargo of $\beta$-cell ISGs, is converted to insulin and C-peptide and non-resident granule components are removed as granules become responsive to stimulation (Kuliawat \& Arvan 1992, 1994, Kuliawat et al. 1997, Eaton et al. 2000, Bonnemaison et al. 2014). When obesity and insulin resistance increase demand for hormone, premature ISG exocytosis contributes to the elevated levels of proinsulin and proinsulin processing intermediates in human and rodent serum (Leahy et al. 1991, Alarcon et al. 1995, Seaquist et al. 1996, Kahn \& Halban 1997, Truyen et al. 2005).

At each step of granule life, SGs display distinct release probabilities controlled by dynamic actin-SG associations (Kögel \& Gerdes 2010, Papadopulos 2017). Ordinarily, the functional form of actin is polymeric (F-actin) (Galkin et al. 2015). Hormone output depends on F-actin for SG transport from intracellular locations and then depolymerization of cortical F-actin for SG access to exocytic sites (Jewell et al. 2008). Among the GTPases that regulate these events is Rac1, which cycles between the inactive GDP-bound and active GTP-bound states and GEFs are a key part of controlling Rac1 activity (Hodge $\&$ Ridley 2016, Kowluru 2017). Not yet studied in $\beta$-cells, Kalirin and Trio, GEFs for Rac1, affect ISG maturation and release in neurons and pituitary endocrine cells (Xin et al. 2004, Ferraro et al. 2007, Koo et al. 2007).

Glucose-triggered insulin output is generally biphasic: a rapid, short-lasting release of a readily releasable pool (RRP) of granules is followed by slower, longerlasting secretion of the reserve pool (Straub \& Sharp 2002, Rorsman \& Braun 2013). Different secretagogues selectively stimulate the release of insulin from the RRP or the reserve pool. Based on studies with knockout mice, Rac1 is essential for glucose-mobilized, prolonged insulin output, but not for depolarization-stimulated rapid insulin release (Asahara et al. 2013). In this report, we show that Kalirin and Trio are expressed in $\beta$-cells.
Using pharmacological inhibitors of Kalirin/Trio GEF1 activities along with Kalirin-knockout mice, we demonstrate that Kalirin participates selectively in insulin secretory pathways that involve Rac1 activation. Using pulse/chase metabolic labeling and glucagon-like peptide 1 (GLP-1), an incretin which also activates Rac1 (Kalwat \& Thurmond 2013), we show that Kalirin more specifically integrates glucose signaling and granule age-related secretory decisions.

\section{Materials and methods}

\section{Materials}

Monoclonal antibody to unprocessed proinsulin, GS-9A8 developed by O.D. Madsen, was obtained from the Developmental Studies Hybridoma Bank (NICHD and the University of Iowa, Department of Biology, Iowa City, IA, USA). Mouse monoclonal anti-insulin antibody was from USBiological (Swampscott, Mass 01907). Guinea pig polyclonal anti-human insulin antibody was custom made by Covance (Denver, PA, USA). Antibodies to Kalirin (Sec14, CT302) and Trio (spectrins 5 and 6, CT233) have been previously described (McPherson et al. 2005, Yan et al. 2015). The mouse monoclonal antibody that specifically recognizes Rac1 (ARC03), not Rac2, Rac3 or Cdc42 was purchased from Cytoskeleton, Inc. Anti-Na+/K+-ATPAse (NKA) antibody was from Dr W J Ball (University of Cincinnati, OH, USA). Alexa-Fluor-conjugated secondary antibodies, Alexa-Fluor-phalloidin were from Molecular Probes (Eugene, OR, USA) and peroxidase conjugates were from Bio-Rad. EXPRESS ${ }^{35}$ S Protein Labeling Mix and enhanced chemiluminescent detection (ECL) reagents were from PerkinElmer. Methionine/cysteine-deficient and complete DME, RPMI, hypaque, GLP-1 and stock chemicals were from Sigma. Collagenase $\mathrm{P}$ was from Boehringer Mannheim. The Kalirin RhoGEF1-selective inhibitor NPPD (1-(3-nitrophenyl)-1H-pyrrole-2,5dione) was purchased from Chembridge, Inc. and ITX3 (2-[(2,5-dimethyl-1-phenyl-1H-pyrrol-3-yl)methylene]thiazolo[3,2-a]benzimidazol-3(2H)one) was obtained from Sigma-Aldrich, Inc. Insulin concentrations were measured using the Ultra-Sensitive Mouse or Human Insulin ELISA Kit (Crystal Chem Inc.).

\section{Cell culture, GEF1 domain inhibitors and Rac1 FRET biosensor}

Mouse pancreatic $\beta$ cell line $\beta$ TC3 was generously provided by Drs N Fleischer, Albert Einstein College of Medicine and 
S Efrat, Tel Aviv University, Israel (D'Ambra et al. 1990). INS1 (rat) and MIN6B1 cells (Asfari et al. 1992, Lilla et al. 2003) were provided by Dr Philippe Halban (University of Geneva, Switzerland) with permission from Dr Jun-ichi Miyazaki, University of Osaka who produced the maternal MIN6 cell line (Miyazaki et al. 1990). Mouse cell lines were maintained in DMEM containing 10\% fetal bovine serum (FBS), high glucose $(25 \mathrm{mM}), 140 \mu \mathrm{M} \beta$-mercaptoethanol and $0.1 \%$ penicillin-streptomycin (Invitrogen) at $37^{\circ} \mathrm{C}$ in a humidified environment with $5 \% \mathrm{CO}_{2}$. For INS1 cell culture, RPMI (11 mM glucose) was substituted for DMEM and the concentration of $\beta$-mercaptoethanol reduced to $50 \mu \mathrm{M}$. As a quality control, insulin content, glucose responsiveness and basal secretion were checked periodically, but generally, cells sub-cultured up to a passage of 29-32 were used. Inhibitors: To characterize the Kalirin/Trio-Rac1 pathway, the effects of NPPD or ITX3, small-molecule inhibitors specific to the GEF1 domain (Ferraro et al. 2007, Yan et al. 2015), were examined. A $100 \mathrm{mM}$ stock was prepared in DMSO and shortly before use, it was diluted to $100 \mu \mathrm{M}$ with medium. Control treatment with DMSO was done in parallel. For studies probing the effects of GEF1 domain inhibition, these cell permeant inhibitors were added either at the start of the chase period (pulse chase) or during a 3-h preincubation before the start of immunofluorescence-labeling experiments. Plasmid: The Rac1 FRET biosensor to monitor Rac1 localization and activity has been described in detail (Moshfegh et al. 2014, Miskolci et al. 2016) and consisted of monomeric Cerulean (mCerulean) fluorescent protein, two tandem p21-binding domains (PBD; amino-acid residues 70-149) from Pak1, separated by a linker, then followed by monomeric Venus (mVenus) fluorescent protein and a full-length region of Rac1. For ratiometric imaging, $3 \times 10^{5}$ cells were transiently transfected with the Rac1 FRET biosensor using Lipofectamine 2000 (Life Technologies) according to the manufacturer's instructions. Cells mounted on $18 \mathrm{~mm}$ round coverslips were fixed in $3.7 \%$ formaldehyde in PBS and mounted in PBS. Microscope imaging at $60 \times$ magnification and image processing were performed as previously described (Spiering \& Hodgson 2012, Spiering et al. 2013, Hanna et al. 2014). Whole cell average Rac1 activity was determined by thresholding the cell area in the FRET/donor ratio image using Metamorph Software. To measure the 'edge over core' ratio of Rac1 activities, we performed unbiased edge erosion measurements of ratio intensities as described previously (Miskolci et al. 2016). We measured the average FRET/donor intensities within a region defined as distance of ten pixels $(2.2 \mu \mathrm{m})$ from the edge and compared this to the average FRET/donor intensity from the rest of the cell body.

\section{Human islets}

Albert Einstein College of Medicine Institutional Review Board approved all experiments using human islets. Human islets were obtained from the NIH- and JDRFsupported Integrated Islet Distribution Program (iidp.coh. org). Upon arrival, islets were incubated in CMRL 1066, supplemented medium (Mediatech, Inc) containing $5.5 \mathrm{mM}$ glucose, $10 \%$ FBS, $100 \mathrm{U} / \mathrm{mL}$ penicillin and $100 \mu \mathrm{g} / \mathrm{mL}$ streptomycin and incubated at $37^{\circ} \mathrm{C}$ with $5 \%$ $\mathrm{CO}_{2}$. Islets used in experiments were cultured for at least $24 \mathrm{~h}$ but for no longer than 5 days.

\section{Mouse islet isolation}

The Albert Einstein College of Medicine or University of Connecticut Health Center Institutional Animal Care and Use Committee approved all animal experiments. Islet experiments were performed using C57BL/6 WT and Kalirin Spectrin repeat knockout (Kal-KO) mice (JAX 031466) (Mandela et al. 2012). Prior to islet isolation, mice had free access to water, standard laboratory chow and were exposed to a 12-h light and darkness cycle. Islets were isolated using standard collagenase digestion that included a Histopaque centrifugation step (Kinasiewicz et al. 2004). Islets were subsequently cultured overnight in RPMI medium (11 mM glucose) supplemented with 10\% FBS plus antibiotics.

\section{Real-time (quantitative) PCR}

Mouse RNAs were prepared using TRIzol (Life Technologies) as described (Mains et al. 2011, Miller et al. 2017b). Quantitative PCR was performed using primers all designed to have calculated melting temperatures of $60-61^{\circ} \mathrm{C}$ and producing PCR products of length $120 \pm 3 \mathrm{nt}$; all product lengths were verified by gel analyses and products were sequenced to test if they included distinctive RNA splice junctions (Mains et al. 2011, Miller et al. 2017b).

\section{Metabolic labeling and chase incubations}

Prior to the start of experiments, $\beta$ cell lines and islets were incubated for $4 \mathrm{~h}$ in media containing $2 \mathrm{mM}$ glucose, $1 \%$ FBS. Cells were washed with methionine- and cysteinefree RPMI 1640 and then pulse-labeled with [35S]Met/Cys 
for $30 \mathrm{~min}$ in the same medium. Cells were chased for various times in DME, $5 \mathrm{mM}$ glucose for basal or $11-16 \mathrm{mM}$ glucose for stimulated conditions. In some experiments, $11 \mathrm{mM}$ glucose was supplemented by the addition of the incretin glucagon-like peptide-1 (GLP-1) at $10 \mathrm{nM}$ or $\mathrm{KCl}$ at $30 \mathrm{mM}$ final concentration. For studies probing the effects of NPPD or ITX3 $(100 \mu \mathrm{M})$, these cell permeant inhibitors were added either at the start of the chase period or during a 3-h preincubation before the start of the experiment. Potential cellular toxicity was tested using Promega's ToxGlo Assay (Cat \# G8000) according to manufacturer's instructions.

To facilitate media exchanges, islets were transferred to MilliCell-PCF culture plate filter inserts (Millipore) at a density of $\sim 50$ islets/insert. The inserts were placed within individual wells of a 24-well cell culture plate and each well was filled with $0.3 \mathrm{~mL}$ volume of chase media. Media was collected from beneath inserts. Islets were floated by a rapid application of $0.5 \mathrm{~mL}$ of $\mathrm{PBS}$ added to the inserts, and then collected by centrifugation. Islet lysates were normalized to same amount of protein and media volumes were adjusted in proportion to any changes of cell lysate volume.

\section{In vivo secretion studies}

Relevant cellular processes for insulin secretion can be regulated differently in males and females (MauvaisJarvis 2015, Roubtsova et al. 2015, Rutkai et al. 2015, Kusminski et al. 2016). Therefore, male and female mice were first analyzed separately and pooled when no differences could be determined. Experiments were performed at least twice using 5-8 mice/condition, ages 13-16 weeks old.

\section{I-Arginine stimulation}

After a 6-h fast, mice were administered L-arginine by intraperitoneal (i.p.) injection at a dose of $1 \mathrm{mg} / \mathrm{g}$ of body weight. Tail blood was collected prior and $3 \mathrm{~min}$ after L-arginine injection and prepared for plasma. Insulin levels were determined with ELISA kits.

\section{Glucose challenge}

Mice fasted overnight were administered $20 \%$ glucose solution by intraperitoneal (i.p.) injection at a dose of $2 \mathrm{mg} / \mathrm{g}$ of body weight. Tail blood collected prior to and at $60 \mathrm{~min}$ post injection was prepared for plasma. Insulin levels were determined with ELISA kits.
Sample preparation, tricine-SDS-PAGE, phosphorimaging and immunoblot analysis

Cells or islets were first lysed in boiling $1 \%$ SDS. Subsequently, lysates were diluted 1:10 in immunoprecipitation buffer to final concentration of $100 \mathrm{mM} \mathrm{NaCl}, 1 \%$ Triton X-100, $0.2 \%$ Na deoxycholate, $0.1 \%$ SDS, $10 \mathrm{mM}$ EDTA, $10 \mathrm{mM}$ iodoacetamide and $25 \mathrm{mM}$ Tris, $\mathrm{pH}$ 7.4. An antiprotease cocktail of aprotinin $(1 \mathrm{mU} / \mathrm{mL})$, leupeptin $(0.1 \mathrm{mM})$, pepstatin $(10 \mathrm{mM})$, EDTA $(5 \mathrm{mM})$ and diisopropylfluorophosphate $(1 \mathrm{mM})$ was added to both lysates and collected media. Cell debris was removed by centrifugation $(5 \mathrm{~min}$ at $10,000 \boldsymbol{g}$ ) and supernatant was collected. Protein concentrations were determined using the bicinchoninic acid assay (Pierce) and cell lysates were normalized to same amount of protein. Media volumes were adjusted in parallel and in proportion to any changes of cell lysate samples. Both cells and media were precleared by a brief incubation with protein A beads before further analysis. Immunoprecipitated insulin and related peptides were analyzed by SDS 15\%-Tricine-SDSPAGE plus urea using the Schagger and von Jagow Tricine buffer system under nonreducing conditions (Schagger 2006) and as previously described (Kuliawat \& Arvan 1992). For quantitative determinations, dried gels were exposed to a phosphor screen (Molecular Dynamics) for 3-7 days and radioisotope images were captured in a laser scanner (Fujifilm FLA 9000). Quantitative analysis was done using instrument-associated software.

Immunoblot: Immunoprecipitated samples or $50-100 \mu g$ of total cell lysate resolved by gel electrophoresis were transferred to nitrocellulose (semi-dry transfer, $150 \mathrm{~mA}$ for $1-2 \mathrm{~h}$ ). The membranes were blocked with blocking buffer (5\% milk diluted in PBS $0.1 \%$ TweenPBST) for $1 \mathrm{~h}$ at room temperature, and then probed for $2 \mathrm{~h}$ at room temperature $(\mathrm{RT})$ or $\mathrm{ON}\left(4^{\circ} \mathrm{C}\right)$ with primary antisera (as indicated) diluted in 2\% milk, PBST. Proteins recognized by the specific antibodies were visualized with peroxidase-conjugated secondary antibodies (Cell Signaling) and chemiluminescent reagent (PerkinElmer, NEL104001EA) using a LiCor Odyssey scanner. Boxes were manually placed around each band of interest and intralane background subtracted using Odyssey 3.0 analytical software (LiCor, Lincoln, NE, USA).

\section{Fluorescence microscopy}

Cells grown on Rat Tail Collagen I- (Gibco) coated coverslips were fixed in $4 \%$ formaldehyde for $15 \mathrm{~min}$ at RT, permeabilized in $0.1 \%$ Triton-100/PBS (15 min, RT) and 
non-specific binding sites blocked by a 30-min incubation with blocking buffer (5\% BSA, 0.5\% FBS in PBST). Primary antibodies were diluted 1:300 and ALEXA-conjugated secondary antibodies (Molecular Probes) 1:1000. Incubations with primary antibodies were for $3 \mathrm{~h}$ (RT) or $\mathrm{ON}\left(4^{\circ} \mathrm{C}\right)$. Coverslips were mounted on glass slides with Prolong Gold Antifade (Molecular Probes, Invitrogen). Images were acquired with a Leica SP5 or an Axiovert 200 fluorescence microscope (Carl Zeiss Microscopy) with X63 objective.

To quantitate NKA/Rac1 overlap in cells, specifically at the plasma membrane, immunostained images were analyzed using CellProfiler 3.0 imaging software (Bray \& Carpenter 2018). Briefly, the CellProfiler colocalization pipeline was imported from cellprofiler.org; the Hoechst channel identified nuclei as objects in the range of 50-100 pixels. Subsequent detection of cell outlines and Otsu thresholding were used for segmentation of cells into objects. As a measure of NKA:Rac1 colocalization, Pearson correlation coefficients were determined for radial zones at cell edges and values 0.50 and above were taken to represent a modest to high degree of colocalization (Dunn et al. 2011). A total of three experiments were performed. Within a single experiment, five image panels were examined per condition with each panel containing approximately 20 cells per view ( $n \geq 100$ cells).

\section{Transmission electron microscopy (TEM)}

Human and mouse islets or $\beta$-cell lines were fixed with $2.5 \%$ glutaraldehyde in $0.1 \mathrm{M}$ sodium cacodylate buffer, post-fixed with $1 \%$ osmium tetroxide followed by $1 \%$ uranyl acetate, dehydrated through a graded series of ethanol and embedded in LX112 resin (LADD Research Industries, Burlington, VT, USA). Ultrathin sections were cut on a Reichert Ultracut E, stained with uranyl acetate followed by lead citrate and viewed on a JEOL 1200EX transmission electron microscope at $80 \mathrm{kv}$. TEMs (human or mouse islets or $\beta$-cell lines) were analyzed using ImageJ and representative images obtained. SGs density per unit area was assessed.

Pieces of pancreata obtained from WT and Kal-KO mice were fixed in $2.5 \%$ glutaraldehyde in $0.1 \mathrm{M}$ phosphate buffer. The tissue was post-fixed with $1 \%$ osmium tetroxide and $1.5 \%$ potassium ferrocyanide, dehydrated and embedded in Epon. Ultrathin sections were poststained with uranyl acetate and lead citrate and photographed with a Jeol 1400 electron microscope equipped with a Gatan Orius SC 1000B CCD camera. Thirty systematically sampled areas of $\beta$ cells were photographed at 5000x magnification and the diameters of SGs and the electron-dense core of SGs (300 granules in each group) and the distance between peripheral granules and the plasma membrane were measured from coded files. Separately the sections were systematically scanned for Golgi areas, and the diameters of immature granules (identified by the more electron lucent core) were measured. The number

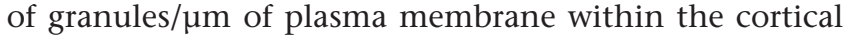
region of the cytoplasm was counted. The cortical region was defined by a distance of one granule diameter (1D) or $\sim 350 \mathrm{~nm}$ from the plasma membrane.

\section{Statistical analyses}

Unless stated otherwise, the reproducibility of findings was confirmed by performing each experiment a minimum of three times. Graphics and statistical analyses were done using the statistical software Prism 7 (GraphPad Software). The data are presented as the mean \pm standard error of the mean (s.e.m.) for all experiments. Two-tailed Student's $t$ test was applied for all pairwise comparisons. Significance was set at $P<0.05$.

\section{Results}

\section{Pancreatic islets and clonal $\beta$-cell lines express the Rho GEFs Kalirin and Trio}

Based on their roles in regulating actin dynamics and insulin secretion in $\beta$-cells, Rac1 GEFs have received much attention (Kowluru 2017). Since granule biogenesis, maturation and exocytosis must be coordinated, regulatory mechanisms must be in place to prevent the premature output of proinsulin-rich ISGs (Eaton et al. 2000, Kogel \& Gerdes 2010, Dehghany et al. 2015). In neurons and corticotropes, two highly homologous members of the Dbl family of Rho GEFs, Kalirin and Trio, regulate F-actin dynamics, Rac1 activity and granule maturation and release (Ferraro et al. 2007, Kiraly et al. 2010), but whether these GEFs coordinate ISG utilization in $\beta$-cells has not yet been explored. Although Kalirin is encoded by a single gene, alternative splicing and the use of multiple promoters generate several functionally distinct isoforms (Fig. 1A) (Miller et al. 2013). In addition to two GEF domains, Kalirin-12, the longest isoform, consists of a Sec14 domain, spectrin-like repeats, two SH3 domains, two Ig/FnIII domains and a kinase-like domain (Fig. 1A). Trio is also subject to alternative splicing (Fig. 1A) (McPherson et al. 2002, Portales-Casamar et al. 2006). Although Kalirin and Trio are clearly not redundant, 
A

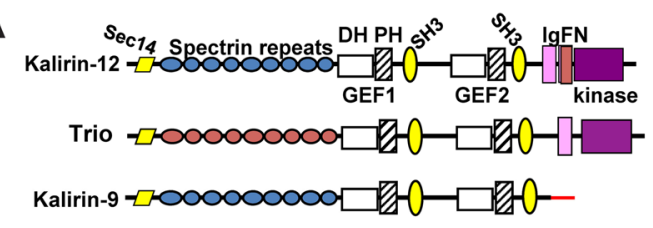

Kalirin-7 -

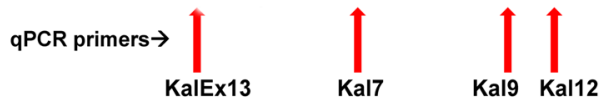

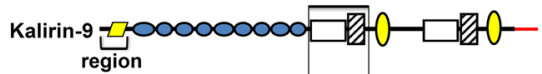

recognized by $\alpha$ Kalirin antibody

Trio-9- $\square 0000-0,000$
region
recognized by $\alpha$ Trio antibody

GEF1: RhoG/Rac1

NPPD/ITX
B

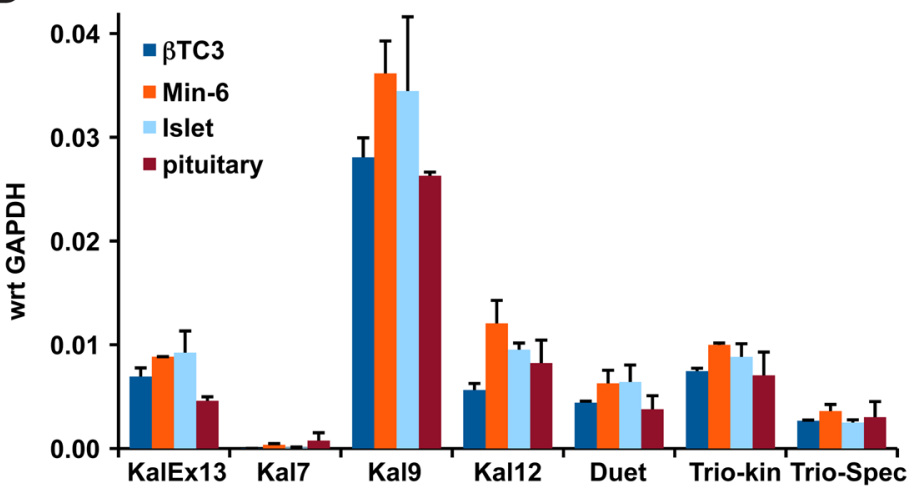

C Kal-KO islets (mouse)

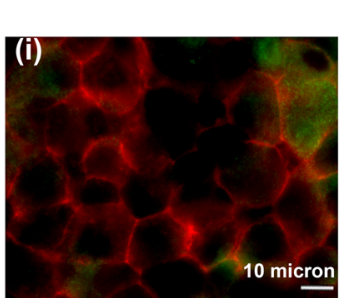

Kalirin (green),

F-actin (red)

D

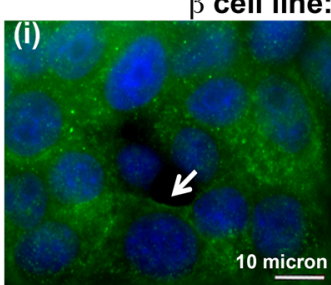

Kalirin (green)

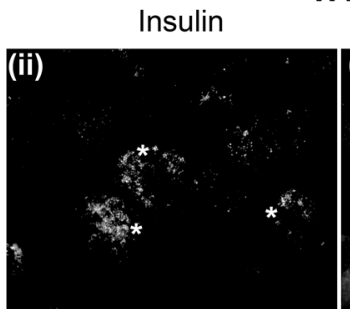

WT Islets (mouse)
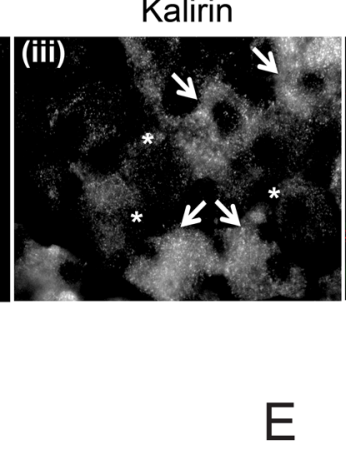

E

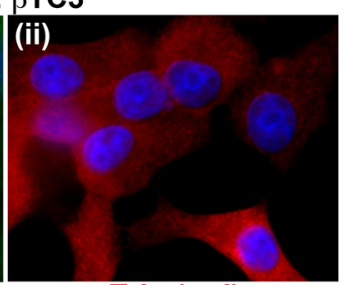

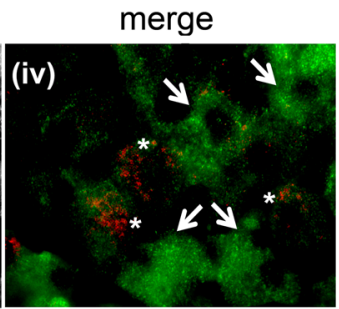

Kalirin (green),

Insulin (red)

IB: $\alpha$ Kalirin
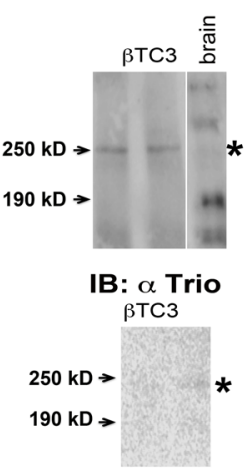

IB: $\alpha$ Gapdh

$37 \mathrm{kD} \rightarrow-$

\section{Figure 1}

$\beta$-Cells express Kalirin and Trio, two homologous GEFs implicated in secretory granule (SG) maturation and exocytosis. (A) Illustration of the multidomain structure shared by Kalirin and Trio: Sec14, Sec14 homology domain; DH, Dbl homology domain; PH, pleckstrin homology domain; SH3, SRC homology 3 domain, Ig, immunoglobulin domain; FN, fibronectin domain. Major Kalirin and Trio splice variants are shown. Regions recognized by the Kalirin (Sec14) and Trio antibodies (spectrin repeats 5 and 6) or targeted by primer pairs (red arrows) in quantitative PCR (qPCR) reactions are indicated. (B) The relative expression of Kalirin and Trio isoforms in mouse islets, $\beta$-cell lines and pituitary as determined by qPCR and normalized to Gapdh. (C) (i) Antiserum to the $\mathrm{N}$-terminus of Kalirin (brackets in A) determines Kalirin distribution within mouse pancreatic islets. Phalloidin stained cortical actin was used to outline cells (red). Insulin positive cells are identified by asterisks and arrows indicate Kalirin positive cells devoid of insulin labeling. (D) Antisera to the N-termini of Kalirin and Trio (brackets in A) determine their cellular localization in $\beta$ TC3 cells (Kalirin, green; Trio, red). Cells were counter stained with DAPI to visualize nuclei. Arrow indicates Kalirin labeling at cell periphery. (E) Expression of endogenous Kalirin and Trio in $\beta$-cell lines was determined by immunoblot. Cell lysates from duplicate wells were normalized to protein concentrations and Gapdh staining served as a loading control. 
their GEF1 domains cannot be distinguished using pharmacological inhibitors (McPherson et al. 2002, 2005, Herring \& Nicoll 2016).

By quantitative PCR (qPCR), we identified expression patterns of several Kalirin and Trio isoforms in islets and $\beta$-cell lines (Fig. 1B). The patterns for endocrine tissues and endocrine cell lines were all very similar, demonstrating a significant amount of transcripts for isoforms including GEF2, the Kal-9-specific 3' UTR, the spectrin region (exon 13) and the kinase region (Kal-12) (Fig. 1B). Transcripts encoding the spectrin repeat region of Kalirin (exon 13) and the Kal-9-specific 3' UTR were most prevalent. As expected, very little of the nervous system-specific isoform, Kal-7, was detected in endocrine tissues (Miller et al. 2013, 2017a). Using similarly located Trio-specific spectrin repeat region and kinase domain primers (Fig. 1A), lower levels of Trio transcript were detected (Fig. 1B).

Kalirin islet distribution was monitored by immunostaining (Fig. 1C). Antibody signal was largely eliminated in islets from Kal-KO mice (Fig. 1C, panel i). As expected, Kalirin staining was readily apparent in control, WT islets (Fig. 1C, panels iii and iv). A side-byside comparison of insulin and Kalirin-stained sections revealed that $\beta$-cells (Fig. 1C, panels ii/iv, asterisks) expressed Kalirin but Kalirin expression was not limited to $\beta$-cells (Fig. 1C, panels iii/iv, arrows). In agreement with the qPCR experiments, immunofluorescence staining of the $\beta$ cell line $\beta$ TC3 confirmed the presence of both GEFs (Fig. 1D, panels i/ii). The diffuse and punctate labeling pattern for Kalirin suggested a cytosolic as well as membrane-associated distribution (Fig. 1D, panel i). Kalirin was also detected at the perimeter of the cell (Fig. 1D, panel i, arrow), a localization not readily seen for Trio (Fig. 1D, panel ii).

To examine Kalirin/Trio protein expression profiles we prepared lysates from MIN6B1, $\beta$ TC3 and INS1 cells ( $\beta$-cell lines) and analyzed them by immunoblot (Fig. 1E). Relative to the loading control (Gapdh), we observed similar levels of Kalirin in all three $\beta$-cell lines (Fig. 1E). In combination with the qPCR results, the predominant, immunoreactive band migrating near the $250 \mathrm{kD}$ molecular weight marker (Fig. 1E, asterisk) identified Kal-9 (Wu et al. 2013) as the major isoform in $\beta$-cells, with no detectable expression of Kal7, which migrates at $190 \mathrm{kD}$. Although barely detectable, the size of the protein band recognized by the Trio antibody suggested Trio-9 (McPherson et al. 2005, PortalesCasamar et al. 2006) was the major isoform in each of the $\beta$-cell lines tested.
Human $\beta$-cells have a high ISG content and exhibit ISG-derived constitutive-like $(C L)$ secretion

During granule maturation, the ISG-derived vesicular pathway primarily removes transiently associated granule content and delivers it to different cellular destinations (Kuliawat \& Arvan 1992, 1994, Klumperman et al. 1998). Although the machinery responsible for this refinement of the organelle remains poorly understood, our previous studies in rodent islets delimited several central parameters: (1) proinsulin, the major soluble cargo of $\beta$-cell ISGs, can be released through direct ISG exocytosis or ISG-derived constitutive-like (CL) secretion (Kuliawat \& Arvan 1992, Kuliawat et al. 1997); (2) CL release is best observed under basal (euglycemic) conditions, when the exocytosis of mature SGs is virtually undetectable (Arvan et al. 1991, Kuliawat \& Arvan 1992); (3) since postgranule vesicular traffic likely merges with the endosomal network, relative to proinsulin processing, CL secretion of prohormone occurs with delayed kinetics (Kuliawat \& Arvan 1992, Kuliawat et al. 1997, Klumperman et al. 1998); (4) continuous proinsulin to insulin conversion gives rise to a mix of proinsulin-derived peptides but as insulin crystals form and the CL pathway continues to sample the ISG fluid phase, CL secretion is enriched in proinsulin and conversion intermediates (Kuliawat et al. 2000).

Unlike rodents, serum samples from healthy human individuals contain elevated levels of proinsulin and partially processed forms, suggesting a species-specific shift toward increased CL release or ISG exocytosis (Zethelius et al. 2003). To elucidate the molecular basis of this secretory activity, we first characterized the cellular localization of proinsulin along the secretory pathway of human $\beta$-cells. At steady state and consistent with a predominantly ISG localization, proinsulin labeling by immunofluorescence was primarily punctate and localized to the perinuclear region (Fig. 2A, panel ii/iii). Electron micrographs of human $\beta$-cells confirmed the presence of electron lucent organelles, a characteristic feature of ISGs (Fig. 2B: ISGs are indicated by arrows, SGs by filled arrows). Indeed, relative to rodent islets and a $\beta$-cell line, quantitative evaluation of electron micrographs demonstrated higher ISG numbers in human $\beta$-cells (Fig. 2C).

Detection of immunoprecipitated proinsulin/insulin after pulse/chase radiolabeling provides one of the most sensitive means for analyzing ISG maturation-dependent CL secretion. To describe the timing and sequence of events leading to production and release of newly made 

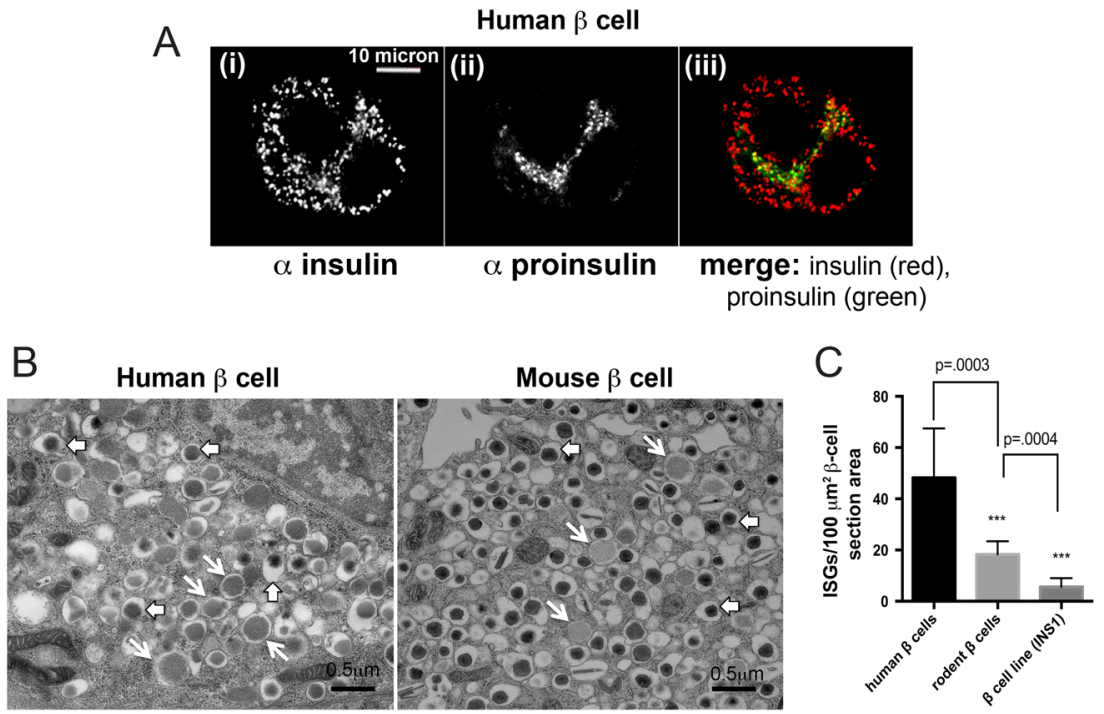

\section{Figure 2}

SG characterization and secretion profiling of human islets demonstrate high ISG content and the presence of ISG-derived, constitutive like vesicular pathway. (A) In the merged image, insulin is stained red, proinsulin green.

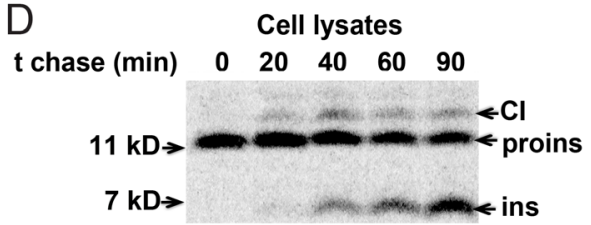

E Media

$t$ chase (hours) $0-1 \quad 1-2 \quad 2-3$

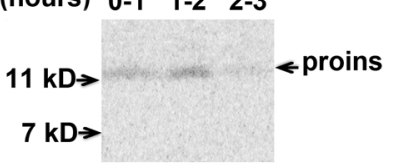

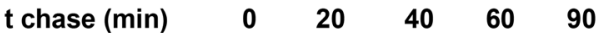

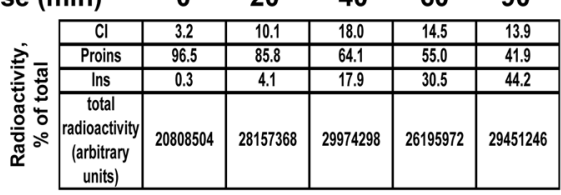

F

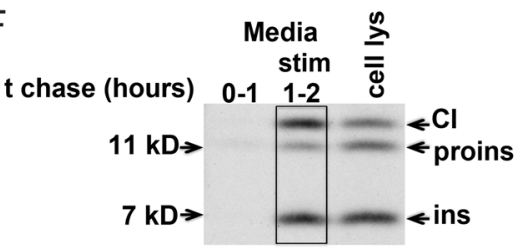

G

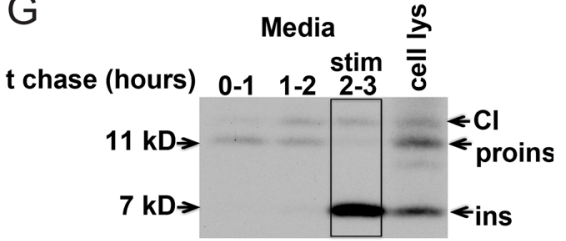

(B) Electron micrographs confirm the presence of ISGs (white arrows, electron lucent content) and mature $\beta$-granules (white filled arrows, electrondense core surrounded by halo) in human and mouse $\beta$-cells. (C) Quantitative evaluation of ISG numbers per $\beta$-cell area in human or rodent islets or INS-1 $\beta$-cell line reveals statistically significant differences in ISG content ( $n=15$ cells). Human vs mouse $\beta$-cells, $P=0.0003$; mouse $\beta$-cells vs INS- 1 cell line, $P=0.0004$. (D) Radiolabeled human islets were chased in $5 \mathrm{mM}$ glucose for the indicated times and immunoprecipitated peptide profiles were determined. Arrowheads indicate intracellular content of proinsulin, conversion intermediates (Cl) and insulin. (E) Media content of hormone collected during three sequential 1-h intervals. (F) Pulse chase experiment repeated with islets from a different donor (media, 0-1 h). Subsequent addition of stimulatory glucose (media, 1-2 h stim). (G) After low glucose (5 mM), exocytosis (16 mM glucose) was examined (media, G: 2-3 h stim, or F: 1-2 h stim). hormone, human islets were radiolabeled for $30 \mathrm{~min}$ (pulse); samples collected after the indicated time interval in label-free medium (chase) were processed as described in 'Methods' section. In $5 \mathrm{mM}$ glucose, processing of newly synthesized proinsulin into its conversion intermediates was reliably detected within $20 \mathrm{~min}$ followed by insulin production after $40 \mathrm{~min}$ of chase (Fig. 2D). Although newly synthesized insulin continued to accumulate in the cells, newly synthesized proinsulin, not insulin, accumulated in the media, peaking during the second hour of collection (Fig. 2E).

In addition to self-limited secretion of prohormone linked to the period of granule maturation, our earlier studies in rodents demonstrated that CL secretion was not sensitive to glucose stimulation (Kuliawat \& Arvan 1992). Therefore, to test for a selective response to elevated glucose, radiolabeled islets from another donor were exposed to $16 \mathrm{mM}$ glucose either at $1-2 \mathrm{~h}$ (Fig. $2 \mathrm{~F}$ ) or $2-3 \mathrm{~h}$ (Fig. $2 \mathrm{G}$ ) of chase. At both times, the cells contained labeled proinsulin (Fig. 2F and G, cell lysates); yet, addition of high glucose primarily altered the secretion of labeled insulin (Fig. $2 \mathrm{~F}$ and G, boxed areas). The data show the presence of a prominent basal, glucose stimulation-independent CL secretory pathway in human $\beta$-cells.

In human islets, KALIRIN/TRIO GEF1 domain inhibition attenuates $C L$ secretion and glucose-mediated SG exocytosis

Two small molecules, NPPD and ITX3, have been shown to be specific inhibitors of the highly conserved GEF1 

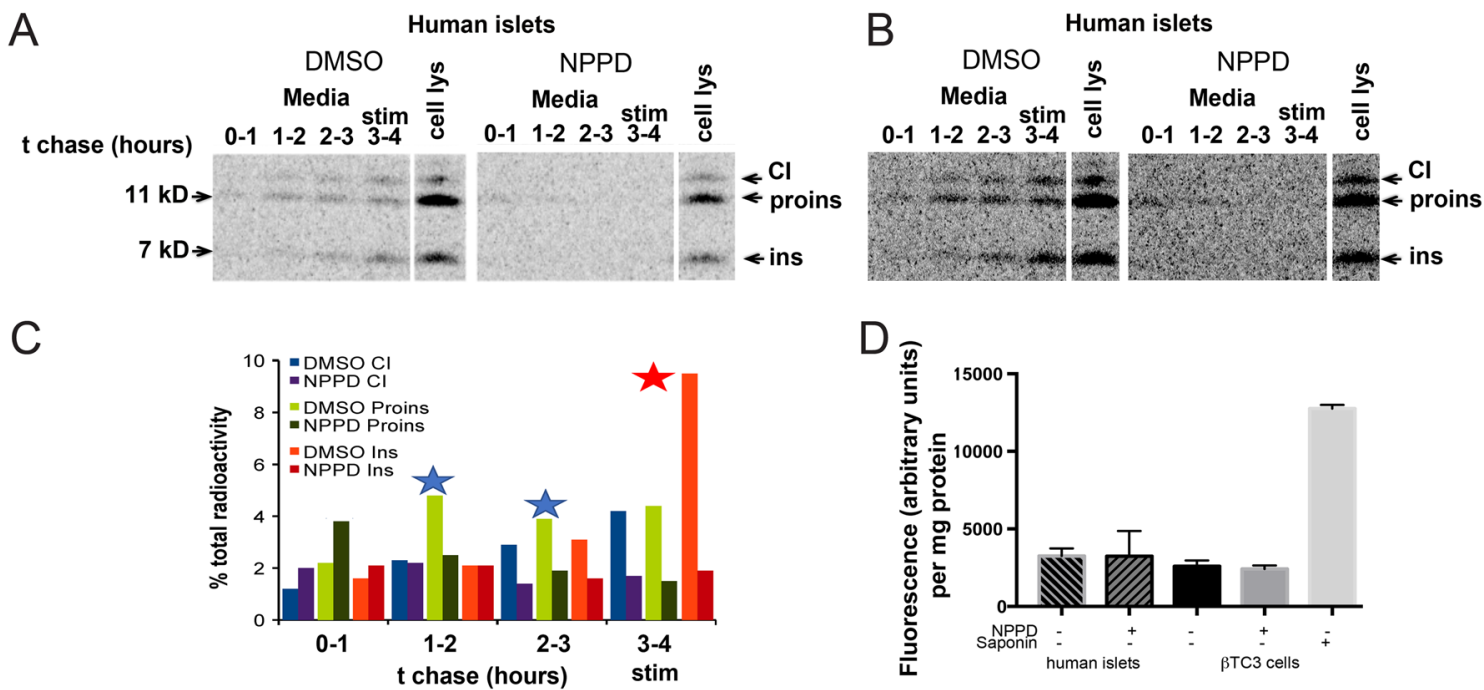

\section{Figure 3}

In human islets, hormone release via constitutive-like vesicular traffic or direct granule exocytosis depends on Kalirin/Trio GEF1 domain activity. (A) Radiolabeled human islets were treated or not with the small molecule inhibitor NPPD, then chased; DMSO was the solvent control. Tricine-SDS-PAGE separation of immunoprecipitated insulin-containing peptides shows hormone content of media collected during four sequential $1 \mathrm{~h}$ intervals $(3 \times 5 \mathrm{mM}$ glucose, $1 \times 16 \mathrm{mM}$ glucose: stim) or retained in the cell (cell lys). (B) For increased sensitivity of detection, a radioautograph was obtained after long (14 day) exposure. (C) Quantification of $\mathrm{Cl}$, Proins and Ins from fluorograms as percent total radioactivity; stars mark significantly altered secretion. (D) Exclusion of fluorogenic peptide (bis-AAF-R110) was used to test cell membrane integrity of healthy cells and fluorescence intensity (Ex/Em: $485 \mathrm{~nm} / 530 \mathrm{~nm}$ ) was normalized to sample protein content. No differences in fluorescence signal were observed with or without NPPD (human islets and $\beta T C 3$ cells). Cell permeabilization with saponin served as a positive control. A full color version of this figure is available at https://doi.org/10.1530/ JME-18-0048.

domains of Kalirin/Trio and at the doses chosen, are not thought to have other targets (Ferraro et al. 2007, Bouquier et al. 2009, Yan et al. 2015). To define a direct biochemical link between Kalirin/Trio function and hormone output, we added vehicle control (DMSO) or NPPD $(100 \mu \mathrm{M})$ to radiolabeled human islets at the start of chase incubations and compared the $\beta$-cell secretory responses under basal and stimulated (3-4h of chase) conditions. The extent of the effect varied, but as measured by proinsulin release under euglycemic conditions, inhibition of Kalirin/Trio GEF1 activity impaired CL secretion and also completely blocked glucose responsive exocytosis of older granules (Fig. 3A). Quantification revealed an inhibitory effect of NPPD on the constitutive and stimulated release of newly synthesized proinsulin and on the stimulated release of newly synthesized insulin (Fig. 3B). To exclude cellular toxicity as a contributor to the reduced secretory responses observed after NPPD exposure, cell viability was assessed using a fluorogenic peptide (Fig. 3D). The intact membranes of healthy cells exclude the peptide; NPPD exposure did not alter islet or $\beta$-cell membrane integrity. At the dose used, inhibition of GEF1 activity was responsible for attenuated hormone output.
Kalirin plays an essential role in glucose-stimulated SG exocytosis in whole animals and regulates proinsulin release by reducing $C L$ secretion and glucose-stimulated ISG exocytosis in isolated islets

The GEF1 domains of Kalirin and Trio are both sensitive to the small-molecule inhibitors NPPD and ITX. Therefore, to distinguish between the roles of Kalirin and Trio, we evaluated insulin secretion in Kalirin-knockout (Kal-KO) mice (Fig. 4). In vivo, $\beta$-cells are innervated, vascularized and interspersed with other pancreatic islet cell types; each of these factors affects regulated insulin secretion (Ahren 2000, Roder et al. 2016). To include any physiologically relevant input, we studied the role of Kalirin in whole animals by evaluating insulin secretion on Kalirinknockout (Kal-KO) mice (Fig. 4A). Plasma insulin levels in WT and Kal-KO mice were measured before and $60 \mathrm{~min}$ after injection of a glucose bolus (intraperitoneally). Strikingly, the response to glucose stimulation decreased in Kal-KO mice, as predicted by the isolated human islet study (Fig. 3A).

To capitalize on the strengths of pulse chase approaches in timing granule age, we radiolabeled islets isolated from WT and Kal-KO mice and monitored basal and glucose-stimulated secretion as a function of chase 
A

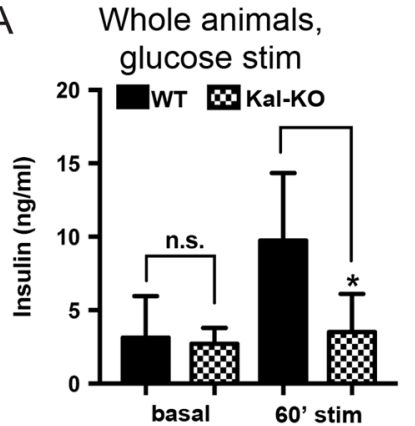

B

Isolated islets, glucose stim

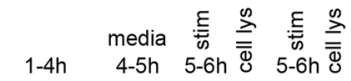

KO WT KO WT KO KO WT WT

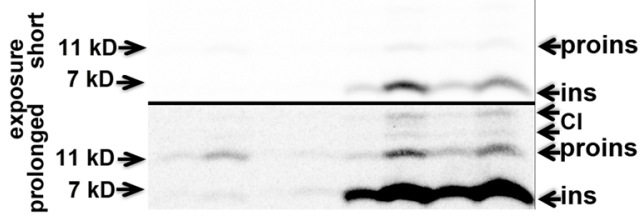

C
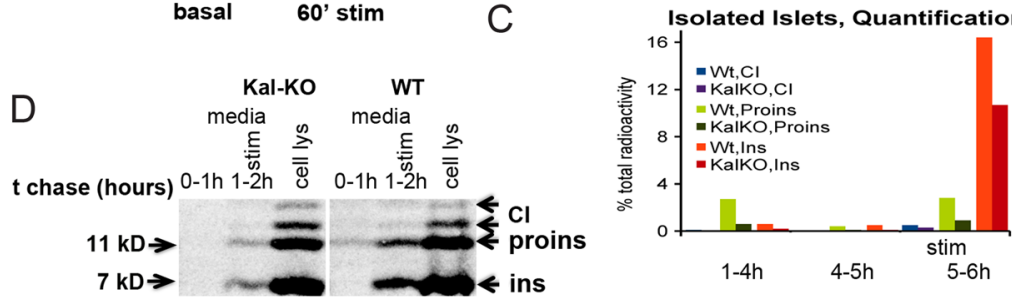

$E$

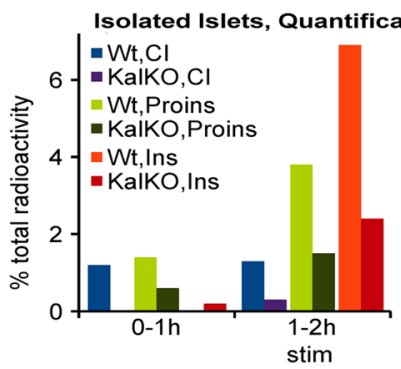

$\mathrm{F}$

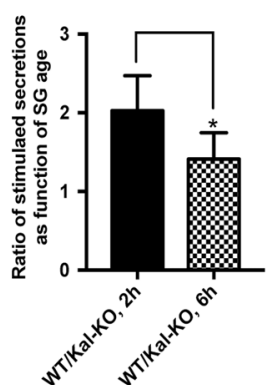

Figure 4

Kalirin elimination reproduces the

pharmacological GEF1 phenotype of impaired glucose-stimulated insulin secretion with an even stronger impact on ISG exocytosis. (A) For in vivo secretion studies, plasma insulin content prior to or $60 \mathrm{~min}$ after an intraperitoneal glucose administration was analyzed using ELISA. (B) Radiolabeled islets (30 min pulse) obtained from WT and Kal-KO mice were chased for three sequential incubations $(2 \times 5 \mathrm{mM}$ glucose, $1-4 \mathrm{~h}$ and $4-5 \mathrm{~h}$, followed by $1 \times 16 \mathrm{mM}$ glucose, $5-6 \mathrm{~h}$ stim). (C) Quantification of total amount of radioactive insulin recovered with stimulation. (D) To focus on the glucose response of newly synthesized granules, the chase time was shortened to $2 \mathrm{~h}$. (E) Quantification. Release of newly synthesized molecules is reduced with loss of Kalirin. (F) Peptides released into media at 2 or $6 \mathrm{~h}$ of chase were quantitated and set up as a ratio (WT/Kal-KO). Results of three secretion experiments done in duplicate were averaged, $P=0.0408$. A full color version of this figure is available at https://doi.org/10.1530/JME-18-0048. time. In agreement with the results for small molecule GEF1 domain inhibition (Fig. 3), genetic Kalirin depletion dramatically attenuated CL release of proinsulin during the 1- to 4-h chase period (Fig. 4B). Without Kalirin, stimulated exocytosis of granules during the 5- to 6-h chase period was also impaired (Fig. 4B, media 5-6h, stim; upper panel shows a lighter exposure; quantified in Fig. 4C).

To focus on the role of Kalirin in secretory function of ISGs, proinsulin/insulin release was monitored by exposing radiolabeled islets to high glucose as a function of short chase times (Fig. 4D). During the first hour of chase, which reflects constitutive plus CL vesicle release, proinsulin secretion was reduced in Kal-KO islets (Fig. 4D and $\mathrm{E}$, media $0-1 \mathrm{~h}$ ). In the absence of Kalirin, the ability of glucose to stimulate the secretion of newly synthesized conversion intermediates, proinsulin and insulin during the second hour of chase decreased markedly (Fig. 4D and E, media 1-2h, stim). Cellular peptide profiles after a 2-h chase were similar in WT and Kal-KO islets and suggested no major processing or degradation defects in Kal-KO $\beta$-cells (Fig. 4D).

After maturation, through a poorly understood process that is completed within about an hour, granule release becomes responsive to glucose stimulation (Kuliawat \& Arvan 1992, 1994). Since granule age dictates how much proinsulin can be released, direct ISG exocytosis could provide an explanation for the partially processed hormone levels found in the circulation of healthy humans that can increase with progression to disease (Ward et al. 1987, Alarcon et al. 1995, Seaquist et al. 1996, Kahn \& Halban 1997, Truyen et al. 2005). To examine if Kalirin contributed to any differences, we compared exocytosis of 2- or 6-h-old granules between WT and Kal-KO islets (as in Figs 4B and 5C). The most pronounced impairment in the glucose responsiveness of Kal-KO $\beta$-cells was observed for young (1-2h old) granules; young granules in WT islets were almost two-fold more sensitive to glucose than granules of the same age in Kal-KO islets (Fig. 4F). Older granules (5-6h old) in WT islets were only 1.4-fold more sensitive to glucose than older granules in Kal-KO islets (Fig. 4F). These experiments demonstrate that for glucose-stimulated ISG exocytosis, Kalirin depletion largely mimics the effects of NPPD, the GEF1 domain inhibitor, suggesting that endogenous $\beta$-cell Trio plays only a minor role in this process. 


\section{Granule size and morphology in Kal-KO islets are indistinguishable from WT}

The details of how granules reach secretion competence are still poorly defined. Nevertheless, a causal connection between achieving regulated exocytosis and the removal of select ISG-associated proteins during maturation has been demonstrated (Eaton et al. 2000, Burgoyne $\&$ Morgan 2003). Ultrastructurally, ISG maturation in $\beta$-cells results in reduction of $\beta$-granule diameter (Orci 1986, Noske et al. 2008) and because this biophysical property lends itself to examination by EM, we isolated and fixed intact pancreata from WT and Kal-KO mice and compared granule morphology (Fig. 5). At the level of overall appearance electron micrographs of WT or Kal-KO islets did not reveal major differences

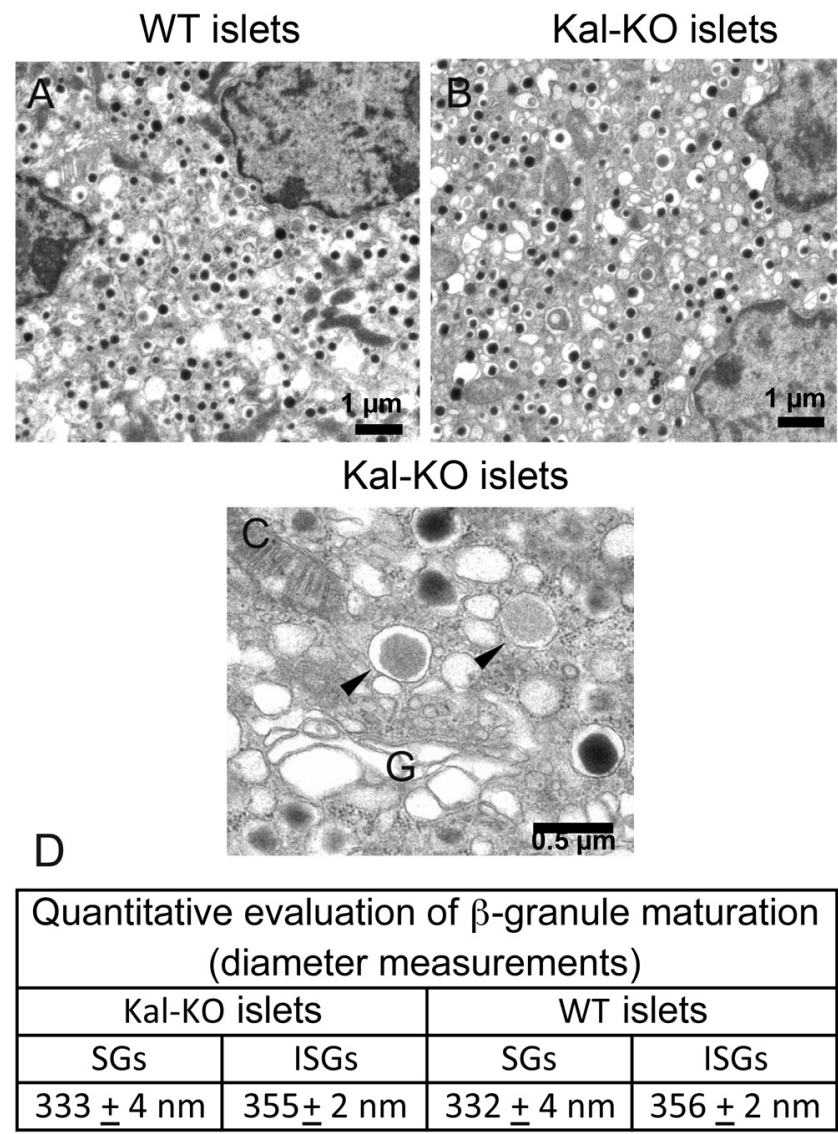

\section{Figure 5}

Change of ISG size during maturation is Kalirin independent. (A, B and C) Electron micrographs of $\beta$-cells from WT $(A)$ and Kal-KO mice (B and C). (A) Electron micrographs of WT or (B) Kal-KO $\beta$-cells obtained from the intact fixed pancreatic tissue reveal no differences in SG morphology. ( $n=2$ animals, tissue from 5 month old female mouse shown). (C) Viewed at higher magnification with particular focus on ISGs in vicinity of the Golgi complex (indicated by arrowheads and G). (D) Quantitative evaluation of beta-cell granule maturation by ultrastructural analyses.
(Fig. 5A, B and C). Measurement of granule diameters also revealed no difference between WT and Kal-KO islets (Fig. 5D). The mean distance between peripheral granules and the plasma membrane $(49 \pm 4 \mathrm{~nm}$ in WT islets vs $55 \pm 4 \mathrm{~nm}$ in Kal-KO islets) and the number of granules within the $350 \mathrm{~nm}$ peripheral zone of the cytoplasm $(1.8 \pm 0.1 / \mu \mathrm{m}$ plasma membrane in WT islets vs $1.7 \pm 0.1$ in Kal-KO islets) were also not significantly different. The EM study shows that Kalirin may not be necessary for normal SGs maturation and migration.

\section{Depolarization-induced insulin release is Kalirin independent}

The exocytosis of granules in the ready releasable pool (RRP) can be stimulated by depolarizing agents and does not require the activation of Rac1 (Seino 2012, Asahara et al. 2013). To test the hypothesis that Kalirin does not play a role in secretory events that bypass Rac1 activation, we used depolarizing agents and measured insulin release in Kal-KO mice and islets (Fig. 6A and B). Although membrane depolarization as the only mechanism by which arginine stimulates insulin secretion has been questioned (Thams \& Capito 1999), arginine remains an effective means to measure $\beta$-cell function in the clinic (Robertson et al. 2014). For our in vivo studies, WT and $\mathrm{Kal}-\mathrm{KO}$ mice were fasted for $6 \mathrm{~h}$ and intraperitoneal injection of arginine was used to stimulate insulin
A

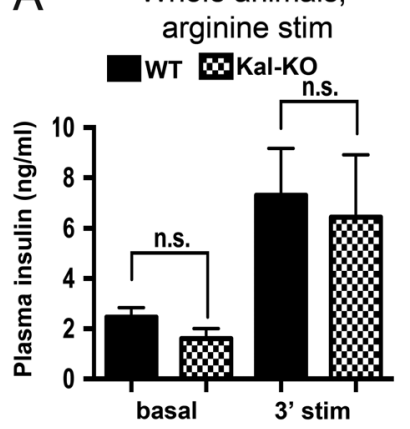

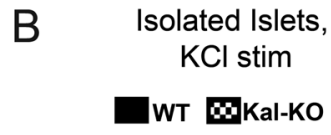

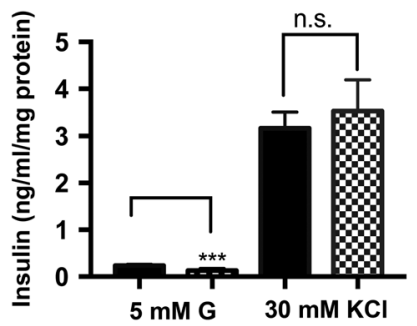

\section{Figure 6}

RRP exocytosis bypasses the need for Kalirin. (A) Release of the RRP of granules was tested in vivo. WT and Kal-KO mice were fasted for $6 \mathrm{~h}$ and plasma samples were taken prior to (basal) and after a 3 min arginine challenge. No significant differences in basal insulin levels or insulin release were observed between WT and Kal-KO mice in response to arginine administration ( $n=7$ animals). (B) Islets isolated from WT and $\mathrm{Kal}-\mathrm{KO}$ mice were exposed for $30 \mathrm{~min}$ to $5 \mathrm{mM}$ glucose or stimulatory (11 mM glucose plus $30 \mathrm{mM} \mathrm{KCl}$ ) conditions. Basal insulin secretion from Kal-KO islets was reduced (WT: $0.24 \pm 0.01$, vs Kal-KO: $0.12 \pm 0.02$,

$P=0.0002)$. Kal-KO and WT islets were equally capable of secreting insulin in response to glucose plus $\mathrm{KCl}$ (WT: $3.2 \pm 0.70$, Kal-KO: $3.5 \pm 0.46$, $P=0.5534)$. 
secretion. Assessment of plasma insulin levels at the start and $3 \mathrm{~min}$ after arginine administration demonstrated no difference in insulin release between WT and Kal-KO mice (Fig. 6A).

Next, we used $\mathrm{KCl}$ to depolarize isolated islets prepared from WT and Kal-KO mice and measured insulin secretion (Fig. 6B). In keeping with the trend toward reduced basal levels of plasma insulin in Kal-KO animals (Fig. 6A), basal secretion in isolated $\mathrm{Kal}-\mathrm{KO}$ islets was attenuated (Fig. 6B), while WT and Kal-KO islets were equally capable of increasing insulin release in response to depolarization by $\mathrm{KCl}$ (Fig. 6B).

\section{Kalirin is needed for glucose-stimulated Rac1 activation in the absence of GLP-1, but not in the presence of GLP-1}

Rac1 is central to the coordination of several signaling pathways and granule exocytosis (Kalwat \& Thurmond 2013). To play its role in insulin release, Rac1 has to translocate from the cytosol to membranes ( $\mathrm{Li}$ et al. 2004). To establish a system in which we could determine whether Kalirin/Trio function plays a role in this process, we looked at Rac1 localization in a $\beta$-cell line in media containing 5 vs $16 \mathrm{mM}$ glucose. To block Rac1 activation by Kalirin/Trio without inactivating other Rho GEFs such as Dbs, Tiam1 or Vav2, two inhibitors are frequently used: NPPD and ITX3 (Blangy \& Fort 2013). In our assays NPPD and ITX3 gave indistinguishable results and here we show the data for ITX3. In $5 \mathrm{mM}$ glucose, Rac1 was distributed throughout the cell; staining for $\mathrm{Na}^{+}, \mathrm{K}^{+}$-ATPase (NKA) marked the plasma membrane (Fig. 7A, upper panels). After a 10-min exposure to $16 \mathrm{mM}$ glucose, Rac1 was concentrated at the plasma membrane, largely co-localized with NKA (Fig. 7A, lower panels). Colocalization of Rac1 and NKA was quantified using Pearson's correlation coefficients (PCCs) (Fig. 7B). Low PCC values observed at $5 \mathrm{mM}$ glucose indicated a lack of NKA:Rac1 correlative distribution (Cordelieres \& Bolte 2014). Increased PCC values observed with $16 \mathrm{mM}$ glucose addition indicated
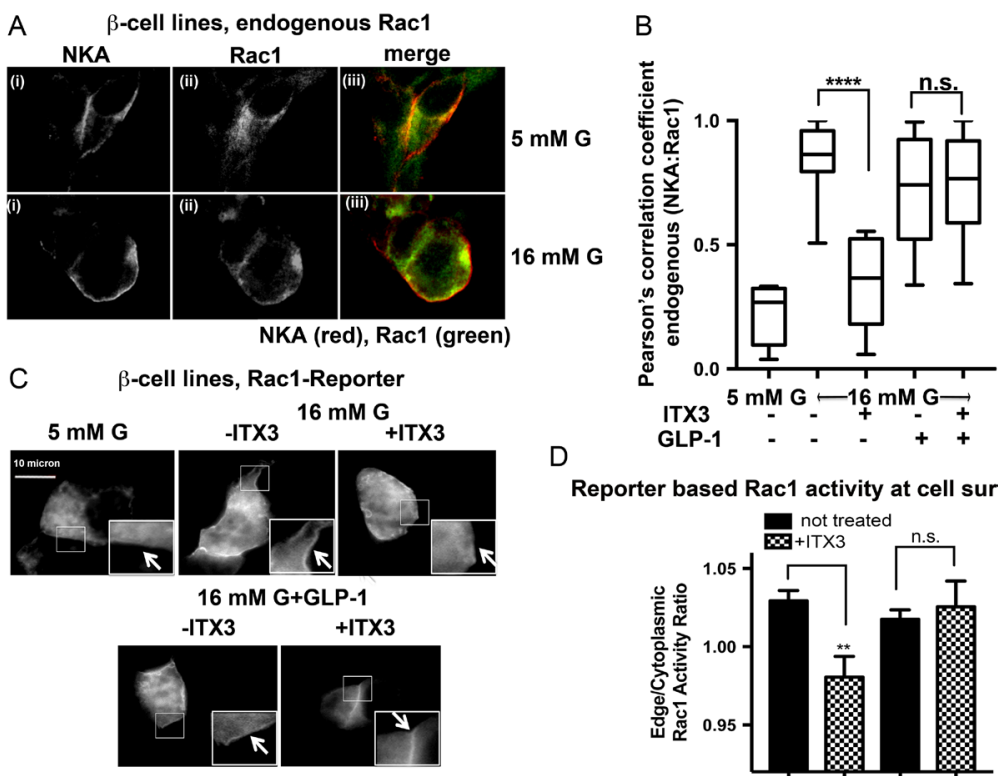

E
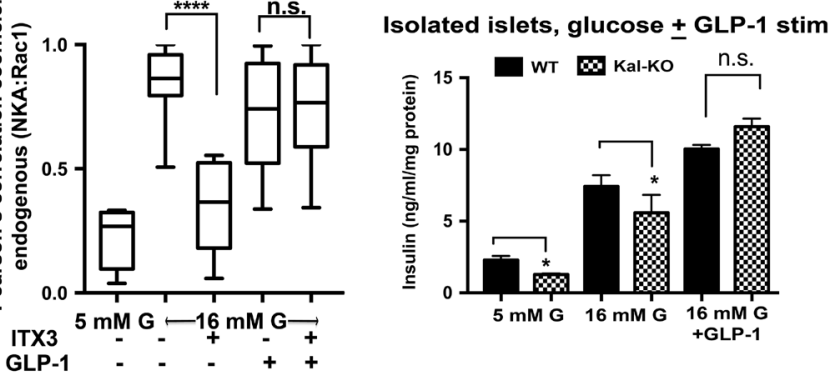

Reporter based Rac1 activity at cell surface

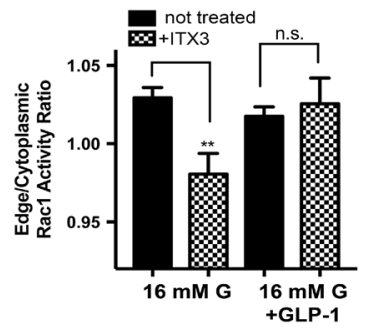

\section{Figure 7}

Drugs targeting Kalirin/Trio GEF1 domain alter Rac1 localization and activity. Simultaneous rescue of Rac1 function and insulin output requires GLP-1 signaling. (A) Rac1 distribution in $\beta$ TC3 cells ( $5 \mathrm{mM} \mathrm{G}$, panels ii, and iii; 10 min at $16 \mathrm{mM} \mathrm{G}$, panels ii and iii) relative to the plasma membrane marker NKA (panel i) was determined by immunofluorescence labeling. (B) NKA:Rac1 colocalization at the cell periphery was quantified using CellProfiler and Pearson's correlation coefficients (PCC) as described in 'Methods' section. Data ( $n \geq 100$ cells per condition) are mean \pm s.E.M. PCC values increased with glucose stimulation ( $16 \mathrm{mM} \mathrm{G}$ : $0.84 \pm 0.03$ vs $5 \mathrm{mM} \mathrm{G:} 0.22 \pm 0.06, P<0.0001$ ) and were attenuated with ITX3 pretreatment ( $16 \mathrm{mM} \mathrm{G}+\mathrm{ITX3}$ : $0.34+0.07$ vs $5 \mathrm{mM} \mathrm{G}: 0.22+0.06, P=0.24$; vs $16 \mathrm{mM} \mathrm{G}$ alone: $0.84+0.03, P<0.0001)$. No significant differences were observed when GLP-1 plus high glucose were used as stimulus (16 mM G + GLP-1, no ITX3: $0.71+0.06$, vs 16 mM G + GLP-1, plus ITX3: $0.75+0.05$, $P=.72$ ). (C) Glucose response of a Rac1 FRET reporter. Small squares denote areas that were enlarged and shown as a magnified area in the lower panel. Redistribution of the reporter \pm ITX and \pm GLP- 1 is shown. (D) FRET/donor intensities of the Rac1 FRET reporter within $2.2 \mu \mathrm{m}$ from the cell's edge were measured and set up as a ratio to the average FRET/donor intensity in the rest of cell ( $n=14 /$ condition). Control vs ITX: $P=0.0027 ; 16 \mathrm{mM} \mathrm{G}+\mathrm{GLP}-1, P=0.6663$. (E) Secretion studies using static incubations of WT or Kal-KO islets exposed to $5 \mathrm{mM}$ glucose or for $10 \mathrm{~min}$ to stimulatory (16 mM glucose or $16 \mathrm{mM}$ glucose plus $10 \mu \mathrm{M}$ GLP-1) conditions. Control vs Kal-KO: $P=0.0489 ; 16 \mathrm{mM} \mathrm{G}+\mathrm{GLP}-1, P=0.0730$. 
that stimulatory glucose augmented the degree of NKA-Rac1 colocalization (Fig. 7A, lower panels, Fig. 7B). When $16 \mathrm{mM}$ glucose plus ITX3 was added to cells, Rac1:NKA signal coincidence was low (Fig. 7A, lower panels, Fig. 7B). In contrast and regardless of the presence or absence of ITX3, addition of high glucose plus GLP-1 resulted in similarly high PCC values (Fig. 7A, lower panels, B). Thus, Rac1 relocation stimulated by $16 \mathrm{mM}$ glucose was sensitive to Kalirin inhibition by ITX3; relocation elicited by GLP-1 in combination with $16 \mathrm{mM}$ glucose was not.

To determine that cell-surface association also represented Rac1 activation, we transiently expressed a genetically encoded FRET-based Rac1 biosensor whose localization and activity have been described in detail (Moshfegh et al. 2014, Miskolci et al. 2016). ITX3 was used to assess the role of Kalirin/Trio in the relocalization and activity of Rac1 in response to high glucose. A shift in biosensor localization at the cell surface could be readily demonstrated in control cells exposed to elevated glucose (Fig. 7C, $5 \mathrm{mM} \mathrm{G}$ and $16 \mathrm{mM}$ G-ITX3 panels); small rectangles indicate areas selected for magnification, arrows pinpoint cell surface. High glucose exposure with ITX3 treatment and reduced Kalirin/Trio GEF1 activity, resulted in a diffuse distribution of the biosensor throughout the cell (Fig. 7C, $16 \mathrm{mM} \mathrm{G}+\mathrm{ITX}$ ), suggesting that Rac1 activation by Kalirin/Trio is essential for its movement onto membranes. While glucose is the principal trigger for stimulated insulin secretion, glucagon-like peptide 1 (GLP-1) augments glucose-dependent release of insulin (Meloni et al. 2013) and acts as an incretin in part by activating Rac1 (Kalwat \& Thurmond 2013). In the presence of high glucose plus GLP-1, ablating Kalirin/Trio GEF1 activity by adding ITX3 did not prevent movement of the Rac1 FRET biosensor onto the plasma membrane (Fig. 7C, $16 \mathrm{mM} \mathrm{G}+$ GLP-1, -ITX3 or +ITX3).

For a quantitative evaluation of cell surface localized activity, we measured the average FRET/donor intensities within a $2.2 \mu \mathrm{m}$ region (10 pixels) from the cell's edge and compared this to the average FRET/donor intensity in the rest of cell body (Fig. 7D). In $16 \mathrm{mM}$ glucose, the addition of ITX3 reduced this ratio, indicating that Kalirin/Trio GEF1 played a role in the increased plasma membrane association of Rac1 activity (Fig. 7D). In contrast, when both glucose and GLP-1 were present, the FRET ratio was no longer sensitive to ITX3 (Fig. 7D), indicating that Kalirin/Trio GEF1 activity was no longer necessary to localize activation of Rac1 to the membrane.

We turned to WT and Kal-KO islets to determine whether GLP-1 had a similarly distinct effect on Rac1 activation in this system. Insulin secretion by WT and Kal-KO islets was measured in $5 \mathrm{mM}$ glucose, $16 \mathrm{mM}$ glucose and $16 \mathrm{mM}$ glucose plus GLP-1 (Fig. 7E). As observed in Fig. 4, insulin secretion was reduced in Kal-KO islets vs WT islets in both 5 and $16 \mathrm{mM}$ glucose. Strikingly, insulin secretion in $16 \mathrm{mM}$ glucose plus GLP-1 was indistinguishable in WT and Kal-KO islets. The similar effects of ITX3 treatment of islets and genetic elimination of Kalirin again argue that it is the GEF1 activity of Kalirin, not Trio, that plays an essential role in the activation of Rac1 by glucose. Loss of Kalirin does not appear to compromise granule exocytosis as such; it affects glucose-stimulated hormone release.

\section{Discussion}

\section{Regulated secretion: examples from the exocrine pancreas}

Regulated secretion is simple enough to measure. However, the different mechanisms through which secretagogues act, and the complex process through which ISGs mature, make it clear that different types of regulated secretion must be distinguished. Our work indicates that Kalirin deficiency in $\beta$-cells impairs CL secretion and granule exocytosis. To gain insight into where along the $\beta$-cell CL secretory pathway Kalirin is required, we turned to exocrine cells, a system in which CL secretion has been studied in more detail. Early work on exocrine tissues distinguished a CL pathway from a minor regulated pathway. Both pathways originate from ISGs, sample granule content through vesicular budding from ISGs and move cargo through endosomal intermediates (Arvan \& Castle 1987, von Zastrow \& Castle 1987, Castle \& Castle 1996). In salivary glands, the minor regulated pathway is mobilized at the beginning of stimulation and creates docking/fusion sites for subsequent direct SG exocytosis (Castle et al. 2002). In the exocrine pancreas, characterization of two ISG associated vSNARES: VAMP2 and VAMP8 (Messenger et al. 2017) led to the discovery that ISGs give rise to VAMP2 or VAMP8 containing zymogen SGs. VAMP2-positive zymogen SG exocytosis is part of an early, short-lasting secretory response. VAMP8positive zymogen SG exocytosis is responsible for the prolonged delivery of digestive enzymes (Messenger et al. 2017). Whereas release of digestive enzymes from VAMP2-positive zymogen SGs is independent of the $\mathrm{CL}$ and minor regulated pathway, activation of the minor regulated pathway is needed for exocytosis of VAMP8-positive zymogen SGs (Messenger et al. 2014). 


\section{The role of endocytic pathways in secretion}

After budding from ISGs, both the CL and minor regulated pathways involve trafficking to an endosomal compartment. The CL pathway routes cargo through recycling endosomes before secretion and the minor regulated pathway directs secretion from early endosomes (Messenger et al. 2013). In addition, the minor regulated pathway can work in concert with CL (Messenger et al. 2015). Acini maintained in tissue culture, for example, rapidly loose VAMP8 expression and with it, the prolonged phase of digestive enzyme secretion (Messenger et al. 2013). Components of the exocytic machinery remain intact and, as anticipated, VAMP8 overexpression rescues this secretory defect. Less predictably, CL pathway activation and overexpression of CL pathway components also restores zymogen SG exocytosis (Messenger et al. 2013, 2015)

\section{How this applies in the endocrine pancreas}

The extent to which similar endosome-associated pathways refine the regulated secretory response in islets/ $\beta$ cells is currently not clearly understood. The association of VAMP2 or VAMP8 with $\beta$-granule exocytosis is well recognized, but no clear relationship to ISG biogenesis has been documented (Liang et al. 2017). Syntaxin 6 (Stx6), a VAMP8 interactor, enters ISGs; upon removal, Stx6 is delivered to endosomes, where it regulates fusion events (Klumperman et al. 1998, Wendler \& Tooze 2001). When a dominant-negative form of Stx6 (Stx6DN) was expressed in $\beta$-cells, removal of procathepsin B from ISGs and trafficking through endosomal compartments were slowed (Kuliawat et al. 2004). Exocytosis of 2-h-old ISGs in response to a combination secretagogue (NeermanArbez \& Halban 1993) was comparable; effects of high glucose alone or depolarizing agents were not investigated (Kuliawat et al. 2004).

\section{The endocrine pancreas has important memory}

In investigations conducted more than 40 years ago, previous exposure to glucose (or other select secretagogues) was shown to change the insulin secretory response to stimulation. This time-dependent potentiation of insulin release did not require the continuous presence of glucose, but 'marked' or changed the stimulus secretion pathway in such a way that the response persisted after glucose was removed. Not all islet secretagogues were marking agents and secretagogue concentrations before or after this critical 'marking' period had little effect. Worthy of note, the critical time period for marking overlapped with ISG formation (Gold et al. 1982, 1984, 1986). It was envisioned that the coincidence of marking/ stimulation by glucose/select secretagogues and granule biogenesis were part of a mechanism to mobilize ISGs when metabolic demand was high. During periods of low metabolic demand, the network deferred ISGs for longerterm storage (Porte \& Pupo 1969, Sando et al. 1972). Albeit an evaluation of marking and its temporal relationship to granule biogenesis awaits the adaptation of islet dynamic perifusion to our system, it is particularly rewarding to note that both the CL pathway and glucose-stimulated insulin secretion, especially as it applies to ISGs, were sensitive to Kalirin/Trio manipulation. Based on the current work, we know that Kalirin/Trio, not previously believed to play a role in pancreatic $\beta$-cells, regulate proinsulin release through the CL pathway in human and rodent islets (Figs 2E, F, G, 3A, B and 4B). Relative to rodents, ISG content in human $\beta$-cells was elevated (Fig. 2B and $\mathrm{C}$ ) suggesting an increased importance of the CL pathway in this tissue. Using Kal-KO mice, we discovered that granule age mattered: exocytosis of newly synthesized proinsulin-rich granules was particularly dependent on Kalirin function (Fig. 4F).

A noteworthy characteristic shared by proinsulin-rich ISGs and another well-characterized pool of granules, 'newcomer granules', is internal cellular distribution. The importance of granule localization lies in the need for cellular mechanisms to select granules for longrange transport to the cell surface and rapid engagement with the exocytic apparatus (Gaisano 2014, GreitzerAntes et al. 2018). Whether ISGs represent a subpopulation of 'newcomer granules' needs to be directly tested; nevertheless, the mechanisms regulating 'newcomer' granule fusion provide insight for future testing of Kalirin function. For example, in striking contrast to the lack of Kalirin participation in first phase hormone output, insulin receptor signaling and activation of phosphatidylinositol 3-kinase (PI3K) clearly target the rapid exocytosis of granules (Aoyagi et al. 2010). As expected, inhibiting PI3K attenuated first phase insulin release; less anticipated was the observation that PI3K inhibition potentiated second phase insulin secretion (Aoyagi et al. 2010). Of note, acute PI3K inhibition increased insulin release by selectively augmenting motility and 'newcomer granule' fusion, which depended on phosphoinositide (PI) signaling (Aoyagi et al. 2010, 2012). Changes in PI abundance lead to Rac1/cytoskeletal alterations that largely depend on GEF activation and membrane association (Welch et al. 2003). 
For Kalirin, membrane interactions are mediated in part by its Sec14 domain (Miller et al. 2015). Of great interest therefore is the fact that the ability of Kalirin to interact with phosphoinositides is regulated by promoter usage (Miller et al. 2015). Direct ISG exocytosis or ISGderived vesicular budding reactions appear to provide an explanation for the species-specific, elevated proinsulin levels found in the circulation of healthy humans. The regulation of Kalirin's ability to integrate PI-based signaling and function, especially when obesity with its elevated demand for hormone drives the use of ISGs, should provide important clues.

\section{Mechanisms of rapid and slower regulated secretion}

Mechanisms remain incomplete and explanations of how SGs may partition into functional pools are not yet solidly explained (Dun et al. 2017). Nevertheless, granules are known to release cargo within minutes or after prolonged glucose elevation. What has been categorized as the RRP can be mobilized rapidly by glucose or by depolarizing agents (Fridlyand \& Philipson 2011). Considered Rac1 insensitive, RRP exocytosis achieved by plasma membrane depolarization was independent of Kalirin (Fig. 6). These experiments were in agreement with the view that Kalirin facilitates SG exocytosis primarily through the Kalirin-Rac1 regulatory cascade. By demonstrating that Kalirin's downstream effector Rac1 links elevated glucose and insulin secretion to Kalirin, this current work delineated potential mechanisms. One well-studied role of Rac1 activity is its stimulus-regulated transit to the plasma membrane, and indeed our characterizations demonstrate that Rac1 activation at the cell surface depends on Kalirin/Trio. Rac1, however, can be trafficked and play important roles at other cellular locations, including shuttling Rac1 to endosomes for an encounter with an activated GEF (Palamidessi et al. 2008). Apart from signaling, Rac1 recruitment/association with select adaptors (i.e. Rab7) in itself may regulate early-to-late endosome trafficking (Margiotta et al. 2017). Without Kalirin/Trio function, CL pathway-mediated vesicular traffic fails to efficiently deliver ISG-derived cargo to the cell's exterior. Whether this failure to secrete involves degradation or cargo accumulation in intracellular compartments, or the identity of such compartments, will require additional work. Moreover, non-stimulatory conditions for Rac1 targeting to endosomes and any involvement of Kalirin/ Trio/Rab7 are still open questions in $\beta$-cells.

\section{Role of Rac1 in insulin secretion}

Although CL pathway dependence on Rac1 remains to be explored, what happens to stimulated insulin secretion with Rac1 manipulation has been reported (Li et al. 2004, Veluthakal et al. 2009). Overexpression of Rac1 or a constitutively active Rac1 mutant (V12Rac1) has no significant effect on basal or stimulated insulin secretion. Much like Kalirin/Trio GEF1 inhibition or Kalirin ablation, direct Rac1 inhibition or expression of a dominant-negative Rac1 mutant (N17Rac1) prevents Rac1 activation/membrane recruitment. It also selectively impairs glucose but not KCl-stimulated insulin secretion (Li et al. 2004, Veluthakal et al. 2009). Thus, together with our current observations, Kalirin's participation in glucose-stimulated hormone output appears to be upstream of the Rac1 regulatory node. These new insights suggest that obesity and the high metabolic demand this state represents may organize $\beta$-cell secretory responses based in part on Kalirin's ability to regulate Rac1.

\section{Declaration of interest}

The authors declare that there is no conflict of interest that could be perceived as prejudicing the impartiality of the research reported. The content of the article is solely the responsibility of the authors and does not necessarily represent the official views of the National Institutes of Health.

\section{Funding}

The work was supported by National Institutes of Health grants DK068843 (R K), CA205262 and GM129098 (L H), DK032948 (B A E, R E M), Einstein Research Fellowship, Office of Medical Student Research, Office of Medical Education, Albert Einstein College of Medicine and the Medical Scholars Program (Q D), Finska Läkaresällskapet and the Perklén Foundation (N B). Human pancreatic islets were provided by the NIDDK-funded Integrated Islet Distribution Program at City of Hope, NIH Grant \# 2UC4DK098085. The authors thank J Nachbar for expert assistance with using Image for analysis of images and the Analytical Imaging Facility of the Albert Einstein College of Medicine as well as the $\mathrm{NCl}$ cancer center that provides them with support (grant P30CA013330) for the use of microscopes. Peng Guo, Einstein's local expert on Light Microscopy \& Image Analysis was instrumental in getting us started with the quantitative evaluation of images. R Muzumdar and L Klein provided much help in setting up the ELISA assays and the general advice of Weiss laboratory members is also gratefully acknowledged. The authors thank the Electron Microscopy Unit of the Institute of Biotechnology, University of Helsinki, for providing laboratory facilities.

\section{Author contribution statement}

R K and Q D designed and performed experiments; R M did the qPCR and $H T$ the animal secretion assays; $L H$ provided expression vectors and performed the FRET analysis; N B did the electron microscopy and ultrastructural image evaluation; $\mathrm{P} M$ developed the Kal-KO mice (JAX031466); R K, B E, R M and N B wrote the paper. 


\section{References}

Ahren B 2000 Autonomic regulation of islet hormone secretion implications for health and disease. Diabetologia 43 393-410. (https://doi.org/10.1007/s001250051322)

Alarcon C, Leahy JL, Schuppin GT \& Rhodes CJ 1995 Increased secretory demand rather than a defect in the proinsulin conversion mechanism causes hyperproinsulinemia in a glucose-infusion rat model of non-insulin-dependent diabetes mellitus. Journal of Clinical Investigation 95 1032-1039. (https://doi.org/10.1172/JCI117748)

Aoyagi K, Ohara-Imaizumi M, Nishiwaki C, Nakamichi Y \& Nagamatsu S 2010 Insulin/phosphatidylinositol 3-kinase pathway accelerates the glucose-induced first phase insulin secretion through TrpV2 recruitment in pancreatic beta-cells. Biochemical Journal 432 375-386. (https://doi.org/10.1042/BJ20100864)

Aoyagi K, Ohara-Imaizumi M, Nishiwaki C, Nakamichi Y, Ueki K, Kadowaki T \& Nagamatsu S 2012 Acute inhibition of PI3K-PDK1-Akt pathway potentiates insulin secretion through upregulation of newcomer granule fusions in pancreatic beta-cells. PLOS ONE 7 e47381. (https://doi.org/10.1371/journal.pone.0047381)

Arvan P \& Castle JD 1987 Phasic release of newly synthesized secretory proteins in the unstimulated rat exocrine pancreas. Journal of Cell Biology 104 243-252. (https://doi.org/10.1083/jcb.104.2.243)

Arvan P \& Castle D 1998 Sorting and storage during secretory granule biogenesis: looking backward and looking forward. Biochemical Journal 332 593-610. (https://doi.org/10.1042/bj3320593)

Arvan P, Kuliawat R, Prabakaran D, Zavacki AM, Elahi D, Wang S \& Pilkey D 1991 Protein discharge from immature secretory granules displays both regulated and constitutive characteristics. Journal of Biological Chemistry 266 14171-14174.

Asahara S, Shibutani Y, Teruyama K, Inoue HY, Kawada Y, Etoh H, Matsuda T, Kimura-Koyanagi M, Hashimoto N, Sakahara M, et al. 2013 Ras-related C3 botulinum toxin substrate 1 (RAC1) regulates glucosestimulated insulin secretion via modulation of F-actin. Diabetologia 56 1088-1097. (https://doi.org/10.1007/s00125-013-2849-5)

Asfari M, Janjic D, Meda P, Li G, Halban PA \& Wollheim CB 1992 Establishment of 2-mercaptoethanol-dependent differentiated insulin-secreting cell lines. Endocrinology 130 167-178. (https://doi. org/10.1210/endo.130.1.1370150)

Blangy A \& Fort P 2013 Targeting the Dbl and dock-family RhoGEFs: a yeast-based assay to identify cell-active inhibitors of Rho-controlled pathways. Enzymes 33 169-191. (https://doi.org/10.1016/B978-0-12 416749-0.00008-7)

Bonnemaison M, Back N, Lin Y, Bonifacino JS, Mains R \& Eipper B 2014 AP-1A controls secretory granule biogenesis and trafficking of membrane secretory granule proteins. Traffic 15 1099-1121. (https:// doi.org/10.1111/tra.12194)

Borgonovo B, Ouwendijk J \& Solimena M 2006 Biogenesis of secretory granules. Current Opinion in Cell Biology 18 365-370. (https://doi. org/10.1016/j.ceb.2006.06.010)

Bouquier N, Vignal E, Charrasse S, Weill M, Schmidt S, Leonetti JP, Blangy A \& Fort P 2009 A cell active chemical GEF inhibitor selectively targets the Trio/RhoG/Rac1 signaling pathway. Chemistry and Biology 16 657-666. (https://doi.org/10.1016/j. chembiol.2009.04.012)

Bray MA \& Carpenter AE 2018 Quality control for high-throughput imaging experiments using machine learning in cellprofiler. Methods in Molecular Biology 1683 89-112. (https://doi.org/10.1007/978-14939-7357-6_7)

Burgoyne RD \& Morgan A 2003 Secretory granule exocytosis. Physiological Reviews 83 581-632. (https://doi.org/10.1152/ physrev.00031.2002)

Castle JD \& Castle AM 1996 Two regulated secretory pathways for newly synthesized parotid salivary proteins are distinguished by doses of secretagogues. Journal of Cell Science 109 2591-2599.
Castle AM, Huang AY \& Castle JD 2002 The minor regulated pathway, a rapid component of salivary secretion, may provide docking/fusion sites for granule exocytosis at the apical surface of acinar cells. Journal of Cell Science 115 2963-2973.

Cordelieres FP \& Bolte S 2014 Experimenters' guide to colocalization studies: finding a way through indicators and quantifiers, in practice. Methods in Cell Biology 123 395-408. (https://doi.org/10.1016/B9780-12-420138-5.00021-5)

D'Ambra R, Surana M, Efrat S, Starr RG \& Fleischer N 1990 Regulation of insulin secretion from beta-cell lines derived from transgenic mice insulinomas resembles that of normal beta-cells. Endocrinology 126 2815-2822. (https://doi.org/10.1210/endo-126-6-2815)

Dehghany J, Hoboth P, Ivanova A, Mziaut H, Muller A, Kalaidzidis Y, Solimena M \& Meyer-Hermann M 2015 A spatial model of insulingranule dynamics in pancreatic beta-cells. Traffic 16 797-813. (https://doi.org/10.1111/tra.12286)

Dun AR, Lord GJ, Wilson RS, Kavanagh DM, Cialowicz KI, Sugita S, Park S, Yang L, Smyth AM, Papadopulos A, et al. 2017 Navigation through the plasma membrane molecular landscape shapes random organelle movement. Current Biology 27 408-414. (https://doi. org/10.1016/j.cub.2016.12.002)

Dunn KW, Kamocka MM \& McDonald JH 2011 A practical guide to evaluating colocalization in biological microscopy. American Journal of Physiology: Cell Physiology 300 C723-C742. (https://doi. org/10.1152/ajpcell.00462.2010)

Eaton BA, Haugwitz M, Lau D \& Moore HP 2000 Biogenesis of regulated exocytotic carriers in neuroendocrine cells. Journal of Neuroscience 20 7334-7344. (https://doi.org/10.1523/ JNEUROSCI.20-19-07334.2000)

Ferraro F, Ma XM, Sobota JA, Eipper BA \& Mains RE 2007 Kalirin/Trio Rho guanine nucleotide exchange factors regulate a novel step in secretory granule maturation. Molecular Biology of the Cell $\mathbf{1 8}$ 4813-4825. (https://doi.org/10.1091/mbc.e07-05-0503)

Fridlyand LE \& Philipson LH 2011 Coupling of metabolic, second messenger pathways and insulin granule dynamics in pancreatic beta-cells: a computational analysis. Progress in Biophysics and Molecular Biology 107 293-303. (https://doi.org/10.1016/j. pbiomolbio.2011.09.001)

Gaisano HY 2014 Here come the newcomer granules, better late than never. Trends in Endocrinology and Metabolism 25 381-388. (https:// doi.org/10.1016/j.tem.2014.03.005)

Galkin VE, Orlova A, Vos MR, Schröder GF \& Egelman EH 2015 Nearatomic resolution for one state of F-actin. Structure 23 173-182. (https://doi.org/10.1016/j.str.2014.11.006)

Gold G, Gishizky ML \& Grodsky GM 1982 Evidence that glucose 'marks' beta cells resulting in preferential release of newly synthesized insulin. Science 218 56-58. (https://doi.org/10.1126/science.6181562)

Gold G, Pou J, Nowlain RM \& Grodsky GM 1984 Effects of monensin on conversion of proinsulin to insulin and secretion of newly synthesized insulin in isolated rat islets. Diabetes 33 1019-1024. (https://doi.org/10.2337/diab.33.11.1019)

Gold G, Pou J, Gishizky ML, Landahl HD, Grodsky GM 1986 Effects of tolbutamide pretreatment on the rate of conversion of newly synthesized proinsulin to insulin and the compartmental characteristics of insulin storage in isolated rat islets. Diabetes $\mathbf{3 5}$ 6-12. (https://doi.org/10.2337/diab.35.1.6)

31Greitzer-Antes D, Xie L, Qin T, Xie H, Zhu D, Dolai S, Liang T, Kang F, Hardy AB, He Y, et al. 2018 Kv2.1 clusters on beta-cell plasma membrane act as reservoirs that replenish pools of newcomer insulin granule through their interaction with syntaxin-3. Journal of Biological Chemistry 293 6893-6904. (https://doi.org/10.1074/jbc. RA118.002703)

Hanna S, Miskolci V, Cox D \& Hodgson L 2014 A new genetically encoded single-chain biosensor for Cdc42 based on FRET, useful for live-cell imaging. PLOS ONE 9 e96469. (https://doi.org/10.1371/ journal.pone.0096469) 
Herring BE \& Nicoll RA 2016 Kalirin and Trio proteins serve critical roles in excitatory synaptic transmission and LTP. PNAS 113 2264-2269. (https://doi.org/10.1073/pnas.1600179113)

Hodge RG \& Ridley AJ 2016 Regulating Rho GTPases and their regulators. Nature Reviews Molecular Cell Biology 17 496-510. (https:// doi.org/10.1038/nrm.2016.67)

Jewell JL, Luo W, Oh E, Wang Z \& Thurmond DC 2008 Filamentous actin regulates insulin exocytosis through direct interaction with Syntaxin 4. Journal of Biological Chemistry 283 10716-10726. (https:// doi.org/10.1074/jbc.M709876200)

Kahn SE \& Halban PA 1997 Release of incompletely processed proinsulin is the cause of the disproportionate proinsulinemia of NIDDM. Diabetes 46 1725-1732. (https://doi.org/10.2337/diab.46.11.1725)

Kalwat MA \& Thurmond DC 2013 Signaling mechanisms of glucoseinduced F-actin remodeling in pancreatic islet beta cells. Experimental and Molecular Medicine 45 e37. (https://doi.org/10.1038/ emm.2013.73)

Kinasiewicz A, Juszczak M, Pachecka J \& Fiedor P 2004 Pancreatic islets isolation using different protocols with in situ flushing and intraductal collagenase injection. Physiological Research 53 327-333.

Kiraly DD, Eipper-Mains JE, Mains RE \& Eipper BA 2010 Synaptic plasticity, a symphony in GEF. ACS Chemical Neuroscience 1 348-365. (https://doi.org/10.1021/cn100012x)

Klumperman J, Kuliawat R, Griffith JM, Geuze HJ \& Arvan P 1998 Mannose 6-phosphate receptors are sorted from immature secretory granules via adaptor protein AP-1, clathrin, and syntaxin 6-positive vesicles. Journal of Cell Biology 141 359-371. (https://doi. org/10.1083/jcb.141.2.359)

Kogel T \& Gerdes HH 2010 Maturation of secretory granules. Results and Problems in Cell Differentiation 50 1-20. (https://doi. org/10.1007/400_2009_31)

Kögel T \& Gerdes H-H 2010 Maturation of secretory granules. In Cellular Peptide Hormone Synthesis and Secretory Pathways, pp 1-20. Eds JF Rehfeld \& JR Bundgaard. Berlin/Heidelberg: Springer. (https://doi. org/10.1007/400_2009_31)

Koo TH, Eipper BA \& Donaldson JG 2007 Arf6 recruits the Rac GEF Kalirin to the plasma membrane facilitating Rac activation. BMC Cell Biology 8 29. (https://doi.org/10.1186/1471-2121-8-29)

Kowluru A 2017 Tiam1/Vav2-Rac1 axis: a tug-of-war between islet function and dysfunction. Biochemical Pharmacology 132 9-17. (https://doi.org/10.1016/j.bcp.2017.02.007)

Kuliawat R \& Arvan P 1992 Protein targeting via the 'constitutive-like' secretory pathway in isolated pancreatic islets: passive sorting in the immature granule compartment. Journal of Cell Biology 118 521-529. (https://doi.org/10.1083/jcb.118.3.521)

Kuliawat R \& Arvan P 1994 Distinct molecular mechanisms for protein sorting within immature secretory granules of pancreatic beta-cells. Journal of Cell Biology 126 77-86. (https://doi.org/10.1083/ jcb.126.1.77)

Kuliawat R, Klumperman J, Ludwig T \& Arvan P 1997 Differential sorting of lysosomal enzymes out of the regulated secretory pathway in pancreatic beta-cells. Journal of Cell Biology 137 595-608. (https:// doi.org/10.1083/jcb.137.3.595)

Kuliawat R, Prabakaran D \& Arvan P 2000 Proinsulin endoproteolysis confers enhanced targeting of processed insulin to the regulated secretory pathway. Molecular Biology of the Cell 11 1959-1972. (https://doi.org/10.1091/mbc.11.6.1959)

Kuliawat R, Kalinina E, Bock J, Fricker L, McGraw TE, Kim SR, Zhong J, Scheller R \& Arvan P 2004 Syntaxin-6 SNARE involvement in secretory and endocytic pathways of cultured pancreatic beta-cells. Molecular Biology of the Cell 15 1690-1701. (https://doi.org/10.1091/ mbc.e03-08-0554)

Kusminski CM, Chen S, Ye R, Sun K, Wang QA, Spurgin SB, Sanders PE, Brozinick JT, Geldenhuys WJ, Li WH, et al. 2016 MitoNEET-Parkin effects in pancreatic alpha- and beta-cells, cellular survival, and intrainsular cross talk. Diabetes 65 1534-1555. (https://doi. org/10.2337/db15-1323)

Leahy JL, Halban PA \& Weir GC 1991 Relative hypersecretion of proinsulin in rat model of NIDDM. Diabetes 40 985-989. (https:// doi.org/10.2337/diab.40.8.985)

Li J, Luo R, Kowluru A \& Li G 2004 Novel regulation by Rac1 of glucoseand forskolin-induced insulin secretion in INS-1 beta-cells. American Journal of Physiology: Endocrinology and Metabolism 286 E818-E827. (https://doi.org/10.1152/ajpendo.00307.2003)

Liang T, Qin T, Xie L, Dolai S, Zhu D, Prentice KJ, Wheeler M, Kang Y, Osborne L \& Gaisano HY 2017 New roles of syntaxin-1A in insulin granule exocytosis and replenishment. Journal of Biological Chemistry 292 2203-2216. (https://doi.org/10.1074/jbc.M116.769885)

Lilla V, Webb G, Rickenbach K, Maturana A, Steiner DF, Halban PA \& Irminger JC 2003 Differential gene expression in well-regulated and dysregulated pancreatic beta-cell (MIN6) sublines. Endocrinology 144 1368-1379. (https://doi.org/10.1210/en.2002-220916)

Loh YP, Kim T, Rodriguez YM \& Cawley NX 2004 Secretory granule biogenesis and neuropeptide sorting to the regulated secretory pathway in neuroendocrine cells. Journal of Molecular Neuroscience 22 63-71. (https://doi.org/10.1385/JMN:22:1-2:63)

Low JT, Mitchell JM, Do OH, Bax J, Rawlings A, Zavortink M, Morgan G, Parton RG, Gaisano HY \& Thorn P 2013 Glucose principally regulates insulin secretion in mouse islets by controlling the numbers of granule fusion events per cell. Diabetologia $\mathbf{5 6}$ 2629-2637. (https://doi.org/10.1007/s00125-013-3019-5)

Mains RE, Kiraly DD, Eipper-Mains JE, Ma XM \& Eipper BA 2011 Kalrn promoter usage and isoform expression respond to chronic cocaine exposure. BMC Neuroscience 12 20. (https://doi.org/10.1186/14712202-12-20)

Mandela P, Yankova M, Conti LH, Ma XM, Grady J, Eipper BA \& Mains RE 2012 Kalrn plays key roles within and outside of the nervous system. BMC Neuroscience 13 136. (https://doi. org/10.1186/1471-2202-13-136)

Margiotta A, Progida C, Bakke O \& Bucci C 2017 Rab7a regulates cell migration through Rac1 and vimentin. Biochimica et Biophysica Acta 1864 367-381. (https://doi.org/10.1016/j.bbamcr.2016.11.020)

Mauvais-Jarvis F 2015 Sex differences in metabolic homeostasis, diabetes, and obesity. Biology of Sex Differences 6 14. (https://doi. org/10.1186/s13293-015-0033-y)

McPherson CE, Eipper BA \& Mains RE 2002 Genomic organization and differential expression of Kalirin isoforms. Gene 284 41-51. (https:// doi.org/10.1016/S0378-1119(02)00386-4)

McPherson CE, Eipper BA \& Mains RE 2005 Multiple novel isoforms of Trio are expressed in the developing rat brain. Gene 347 125-135. (https://doi.org/10.1016/j.gene.2004.12.028)

Meloni AR, DeYoung MB, Lowe C \& Parkes DG 2013 GLP-1 receptor activated insulin secretion from pancreatic beta-cells: mechanism and glucose dependence. Diabetes, Obesity and Metabolism 15 15-27. (https://doi.org/10.1111/j.1463-1326.2012.01663.x)

Messenger SW, Thomas DD, Falkowski MA, Byrne JA, Gorelick FS \& Groblewski GE 2013 Tumor protein D52 controls trafficking of an apical endolysosomal secretory pathway in pancreatic acinar cells. American Journal of Physiology: Gastrointestinal and Liver Physiology 305 G439-G452. (https://doi.org/10.1152/ajpgi.00143.2013)

Messenger SW, Falkowski MA, Thomas DD, Jones EK, Hong W, Gaisano HY, Boulis NM \& Groblewski GE 2014 Vesicle associated membrane protein 8 (VAMP8)-mediated zymogen granule exocytosis is dependent on endosomal trafficking via the constitutive-like secretory pathway. Journal of Biological Chemistry 289 28040-28053. (https://doi.org/10.1074/jbc.M114.593913)

Messenger SW, Thomas DD, Cooley MM, Jones EK, Falkowski MA, August BK, Fernandez LA, Gorelick FS \& Groblewski GE 2015 Early to late endosome trafficking controls secretion and zymogen activation in rodent and human pancreatic acinar cells. Cellular and 
Molecular Gastroenterology and Hepatology 1 695-709. (https://doi. org/10.1016/j.jcmgh.2015.08.002)

Messenger SW, Jones EK, Holthaus CL, Thomas DDH, Cooley MM, Byrne JA, Mareninova OA, Gukovskaya AS \& Groblewski GE 2017 Acute acinar pancreatitis blocks vesicle-associated membrane protein 8 (VAMP8)-dependent secretion, resulting in intracellular trypsin accumulation. Journal of Biological Chemistry 292 7828-7839. (https://doi.org/10.1074/jbc.M117.781815)

Miller MB, Yan Y, Eipper BA \& Mains RE 2013 Neuronal Rho GEFs in synaptic physiology and behavior. Neuroscientist 19 255-273. (https://doi.org/10.1177/1073858413475486)

Miller MB, Vishwanatha KS, Mains RE \& Eipper BA 2015 An N-terminal amphipathic helix binds phosphoinositides and enhances kalirin Sec14 domain-mediated membrane interactions. Journal of Biological Chemistry 290 13541-13555. (https://doi.org/10.1074/jbc. M115.636746)

Miller MB, Yan Y, Machida K, Kiraly DD, Levy AD, Wu YI, Lam TT, Abbott T, Koleske AJ, Eipper BA, et al. 2017a Brain region and isoform-specific phosphorylation alters Kalirin SH2 domain interaction sites and calpain sensitivity. ACS Chemical Neuroscience 8 1554-1569. (https://doi.org/10.1021/acschemneuro.7b00076)

Miller MB, Yan Y, Wu Y, Hao B, Mains RE \& Eipper BA 2017b Alternate promoter usage generates two subpopulations of the neuronal RhoGEF Kalirin-7. Journal of Neurochemistry 140 889-902. (https:// doi.org/10.1111/jnc.13749)

Miskolci V, Wu B, Moshfegh Y, Cox D \& Hodgson L 2016 Optical tools to study the isoform-specific roles of small GTPases in immune cells. Journal of Immunology 196 3479-3493. (https://doi.org/10.4049/ jimmunol.1501655)

Miyazaki J, Araki K, Yamato E, Ikegami H, Asano T, Shibasaki Y, Oka Y \& Yamamura K 1990 Establishment of a pancreatic beta cell line that retains glucose-inducible insulin secretion: special reference to expression of glucose transporter isoforms. Endocrinology $\mathbf{1 2 7}$ 126-132. (https://doi.org/10.1210/endo-127-1-126)

Moshfegh Y, Bravo-Cordero JJ, Miskolci V, Condeelis J \& Hodgson L 2014 A Trio-Rac1-Pak1 signalling axis drives invadopodia disassembly. Nature Cell Biology 16 574-586. (https://doi. org/10.1038/ncb2972)

Neerman-Arbez M \& Halban PA 1993 Novel, non-crinophagic, degradation of connecting peptide in transformed pancreatic beta cells. Journal of Biological Chemistry 268 16248-16252.

Noske AB, Costin AJ, Morgan GP \& Marsh BJ 2008 Expedited approaches to whole cell electron tomography and organelle mark-up in situ in high-pressure frozen pancreatic islets. Journal of Structural Biology 161 298-313. (https://doi.org/10.1016/j. jsb.2007.09.015)

Orci L 1986 The morphology of proinsulin processing. Annals of the New York Academy of Sciences 488 292-316. (https://doi. org/10.1111/j.1749-6632.1986.tb46567.x)

Palamidessi A, Frittoli E, Garre M, Faretta M, Mione M, Testa I, Diaspro A, Lanzetti L, Scita G \& Di Fiore PP 2008 Endocytic trafficking of Rac is required for the spatial restriction of signaling in cell migration. Cell 134 135-147. (https://doi.org/10.1016/j. cell.2008.05.034)

Papadopulos A 2017 Membrane shaping by actin and myosin during regulated exocytosis. Molecular and Cellular Neuroscience 84 93-99. (https://doi.org/10.1016/j.mcn.2017.05.006)

Portales-Casamar E, Briancon-Marjollet A, Fromont S, Triboulet R \& Debant A 2006 Identification of novel neuronal isoforms of the RhoGEF Trio. Biology of the Cell 98 183-193. (https://doi.org/10.1042/ BC20050009)

Porte D Jr \& Pupo AA 1969 Insulin responses to glucose: evidence for a two pool system in man. Journal of Clinical Investigation $\mathbf{4 8}$ 2309-2319. (https://doi.org/10.1172/JCI106197)

Robertson RP, Raymond RH, Lee DS, Calle RA, Ghosh A, Savage PJ, Shankar SS, Vassileva MT, Weir GC \& Fryburg DA 2014 Arginine is preferred to glucagon for stimulation testing of beta-cell function. American Journal of Physiology: Endocrinology and Metabolism 307 E720-E727. (https://doi.org/10.1152/ajpendo.00149.2014)

Roder PV, Wu B, Liu Y \& Han W 2016 Pancreatic regulation of glucose homeostasis. Experimental and Molecular Medicine 48 e219. (https:// doi.org/10.1038/emm.2016.6)

Rorsman P \& Braun M 2013 Regulation of insulin secretion in human pancreatic islets. Annual Review of Physiology 75 155-179. (https:// doi.org/10.1146/annurev-physiol-030212-183754)

Roubtsova A, Chamberland A, Marcinkiewicz J, Essalmani R, Fazel A, Bergeron JJ, Seidah NG \& Prat A 2015 PCSK9 deficiency unmasks a sex- and tissue-specific subcellular distribution of the LDL and VLDL receptors in mice. Journal of Lipid Research 56 2133-2142. (https:// doi.org/10.1194/jlr.M061952)

Rutkai I, Dutta S, Katakam PV \& Busija DW 2015 Dynamics of enhanced mitochondrial respiration in female compared with male rat cerebral arteries. American Journal of Physiology: Heart and Circulatory Physiology 309 H1490-H1500. (https://doi.org/10.1152/ ajpheart.00231.2015)

Sando H, Borg J \& Steiner DF 1972 Studies on the secretion of newly synthesized proinsulin and insulin from isolated rat islets of Langerhans. Journal of Clinical Investigation 51 1476-1485. (https:// doi.org/10.1172/JCI106944)

Schagger H 2006 Tricine-SDS-PAGE. Nature Protocols 1 16-22. (https:// doi.org/10.1038/nprot.2006.4)

Seaquist ER, Kahn SE, Clark PM, Hales CN, Porte D Jr \& Robertson RP 1996 Hyperproinsulinemia is associated with increased beta cell demand after hemipancreatectomy in humans. Journal of Clinical Investigation 97 455-460. (https://doi.org/10.1172/JCI118435)

Seino S 2012 Cell signalling in insulin secretion: the molecular targets of ATP, cAMP and sulfonylurea. Diabetologia 55 2096-2108. (https://doi. org/10.1007/s00125-012-2562-9)

Spiering D \& Hodgson L 2012 Multiplex imaging of Rho family GTPase activities in living cells. Methods in Molecular Biology 827 215-234. (https://doi.org/10.1007/978-1-61779-442-1_15)

Spiering D, Bravo-Cordero JJ, Moshfegh Y, Miskolci V \& Hodgson L 2013 Quantitative ratiometric imaging of FRET-biosensors in living cells. Methods in Cell Biology 114 593-609. (https://doi.org/10.1016/B9780-12-407761-4.00025-7)

Straub SG \& Sharp GW 2002 Glucose-stimulated signaling pathways in biphasic insulin secretion. Diabetes/Metabolism Research and Reviews 18 451-463. (https://doi.org/10.1002/dmrr.329)

Thams P \& Capito K 1999 L-arginine stimulation of glucose-induced insulin secretion through membrane depolarization and independent of nitric oxide. European Journal of Endocrinology $\mathbf{1 4 0}$ 87-93. (https://doi.org/10.1530/eje.0.1400087)

Tooze SA, Martens GJ \& Huttner WB 2001 Secretory granule biogenesis: rafting to the SNARE. Trends in Cell Biology 11 116-122. (https://doi. org/10.1016/S0962-8924(00)01907-3)

Truyen I, De Pauw P, Jorgensen PN, Van Schravendijk C, Ubani O, Decochez K, Vandemeulebroucke E, Weets I, Mao R, Pipeleers DG, et al. 2005 Proinsulin levels and the proinsulin:c-peptide ratio complement autoantibody measurement for predicting type 1 diabetes. Diabetologia 48 2322-2329. (https://doi.org/10.1007/ s00125-005-1959-0)

Veluthakal R, Madathilparambil SV, McDonald P, Olson LK \& Kowluru A 2009 Regulatory roles for Tiam1, a guanine nucleotide exchange factor for Rac1, in glucose-stimulated insulin secretion in pancreatic beta-cells. Biochemical Pharmacology 77 101-113. (https://doi. org/10.1016/j.bcp.2008.09.021)

von Zastrow M \& Castle JD 1987 Protein sorting among two distinct export pathways occurs from the content of maturing exocrine storage granules. Journal of Cell Biology 105 2675-2684. (https://doi. org/10.1083/jcb.105.6.2675)

Ward WK, LaCava EC, Paquette TL, Beard JC, Wallum BJ \& Porte D Jr 1987 Disproportionate elevation of immunoreactive proinsulin in 
type 2 (non-insulin-dependent) diabetes mellitus and in experimental insulin resistance. Diabetologia 30 698-702. (https:// doi.org/10.1007/BF00296991)

Welch HC, Coadwell WJ, Stephens LR \& Hawkins PT 2003 Phosphoinositide 3-kinase-dependent activation of Rac. FEBS Letters 546 93-97. (https://doi.org/10.1016/S0014-5793(03)00454-X)

Wendler F \& Tooze S 2001 Syntaxin 6: the promiscuous behaviour of a SNARE protein. Traffic 2 606-611. (https://doi. org/10.1034/j.1600-0854.2001.20903.x)

Wilson DF, Cember ATJ \& Matschinsky FM 2017 The thermodynamic basis of glucose-stimulated insulin release: a model of the core mechanism. Physiological Reports 5 e13327. (https://doi.org/10.14814/phy2.13327)

Wu JH, Fanaroff AC, Sharma KC, Smith LS, Brian L, Eipper BA, Mains RE, Freedman NJ \& Zhang L 2013 Kalirin promotes neointimal hyperplasia by activating Rac in smooth muscle cells. Arteriosclerosis, Thrombosis, and Vascular Biology 33 702-708. (https:// doi.org/10.1161/ATVBAHA.112.300234)

Xin X, Ferraro F, Back N, Eipper BA \& Mains RE 2004 Cdk5 and Trio modulate endocrine cell exocytosis. Journal of Cell Science $\mathbf{1 1 7}$ 4739-4748. (https://doi.org/10.1242/jcs.01333)

Yan Y, Eipper BA \& Mains RE 2015 Kalirin-9 and Kalirin-12 play essential roles in dendritic outgrowth and branching. Cerebral Cortex 25 3487-3501. (https://doi.org/10.1093/cercor/bhu182)

Zethelius B, Byberg L, Hales CN, Lithell H \& Berne C 2003 Proinsulin and acute insulin response independently predict Type 2 diabetes mellitus in men - report from 27 years of follow-up study. Diabetologia 46 20-26. (https://doi.org/10.1007/s00125002-0995-2)

Received in final form 16 October 2018

Accepted 5 November 2018

Accepted Preprint published online 8 November 2018
(C) 2019 Society for Endocrinology Published by Bioscientifica Ltd. Printed in Great Britain 